Adam KIRPSZA

Uniwersytet Jagielloński

a.kirpsza@gmail.com

\title{
SKUTECZNOŚĆ POPRAWEK PARLAMENTU EUROPEJSKIEGO W PROCEDURZE KONSULTACJI (SPECJALNEJ PROCEDURZE USTAWODAWCZEJ)
}

ABSTRACT Effectiveness of the European Parliament amendments in the consultation procedure (special legislative procedure)

The aim of the article is to empirically analyze the effectiveness of the European Parliament's amendments in one of the special legislative procedures, namely consultation. In the first step, several hypotheses were developed predicting positive or negative impact of certain factors on the EP amendments success. Subsequently, those suppositions were quantitatively tested by logistic regression on special dataset representing 599 legislative acts adopted during the fifth and sixth parliamentary term, that is, between 1 May 1999 and June 2009, under consultation. The results revealed that the EP is more likely to be successful in this procedure if it implements five strategies. Firstly, it seeks to conclude a package deal, that is, it links a consultation decision to a codecision or budgetary proposal. Secondly, it delays its opinion on a legislative proposal. Thirdly, it persuades the European Commission to support its amendments. Fourthly, it prolongs legislative negotiations with the Council until the end of parliamentary term. Fifthly, it accumulates all its negotiation resources on salient proposals. In addition, the EP is more likely to succeed in consultation when it proposes democratic and financial amendments, whereas it is least likely to be successful when it tables institutional issues. The success of EP amendments is also significantly greater in directives than in regulations, decisions or framework decisions. On the other hand, voting rule in the Council, rapporteur experience and her/ his political affiliation with EPP-ED, PES or ELDR/ALDE don't have any impact on the EP amendments success. 
Key-words: European Union, special legislative procedure, consultation, European Parliament's amendments success, legislative negotiations

Słowa kluczowe: Unia Europejska, specjalna procedura ustawodawcza, konsultacja, sukces poprawek Parlamentu, negocjacje legislacyjne

\section{WSTĘP}

Celem artykułu jest odpowiedź na następujące pytanie badawcze: jakie czynniki wpływają na sukces poprawek Parlamentu Europejskiego (PE) zgłaszanych do projektów rozpatrywanych w konsultacji (specjalnej procedurze ustawodawczej). Inaczej mówiąc, w jaki sposób Parlament Europejski powinien negocjować z Radą w tej procedurze, aby przeforsować swoje postulaty. W pierwszej części artykułu omówiono przebieg procesu podejmowania decyzji w ramach konsultacji. W drugiej części postawiono kilka hipotez przewidujących stymulujący lub negatywny wpływ określonych czynników na sukces poprawek Parlamentu zgłaszanych w tej procedurze. W części trzeciej opisano metodę empirycznej weryfikacji powyższych przypuszczeń, czyli regresję logistyczną. W części czwartej przedstawiono wyniki testu hipotez. W zakończeniu podsumowano uzyskane wnioski.

\section{CHARAKTERYSTYKA PROCEDURY KONSULTACJI}

Zgodnie z art. 289 ust. 3 TFUE akty ustawodawcze Unii Europejskiej są uchwalane w ramach dwóch procedur prawodawczych: zwykłej procedury ustawodawczej (zmodyfikowanej wersji funkcjonującego wcześniej współdecydowania; ZPU) i specjalnej procedury ustawodawczej (SPU). Pierwsza polega na przyjmowaniu rozporządzeń, dyrektyw i decyzji wspólnie przez Parlament Europejski i Radę na wniosek Komisji, a jej przebieg jest wyczerpująco zdefiniowany w art. 294 TFUE. Natomiast SPU jest stosowana tylko w szczególnych przypadkach przewidzianych w Traktatach i służy przyjmowaniu rozporządzeń, dyrektyw i decyzji przez Parlament Europejski z udziatem Rady lub przez Radę z udziatem Parlamentu Europejskiego. W odróżnieniu od ZPU jej przebieg nie jest opisany w żadnym przepisie prawnym. W rzeczywistości jednak Traktaty nie przewidują jednej SPU, lecz kilka takich procedur, np. konsultacja czy zgoda.

Konsultacja jest jedną z najstarszych i najważniejszych SPU. Została ustanowiona już w traktatach rzymskich z 25 marca 1957 r. i do wejścia w życie Jednolitego Aktu Europejskiego z 17/28 lutego 1986 r., wprowadzającego procedurę współpracy i zgody, była jedyną formułą legislacyjną, w której Parlament partycypował w ustalaniu wspólnotowego prawodawstwa. Jak pokazuje wykres nr 1, właściwie aż do 2008 r. liczba projektów rozpatrywanych w konsultacji była wyższa niż wniosków przyjmowanych w ZPU. Stan ten zmieniło dopiero wejście w życie Traktatu z Lizbony w 2009 r., 
który znacznie zmniejszył zakres stosowania tej pierwszej procedury i uczynił ZPU dominującym trybem uchwalania aktów ustawodawczych.

Wykres 1. Liczba projektów legislacyjnych rozpatrywanych w latach 1993-2014 w procedurze współdecydowania (ZPU) i konsultacji (SPU)

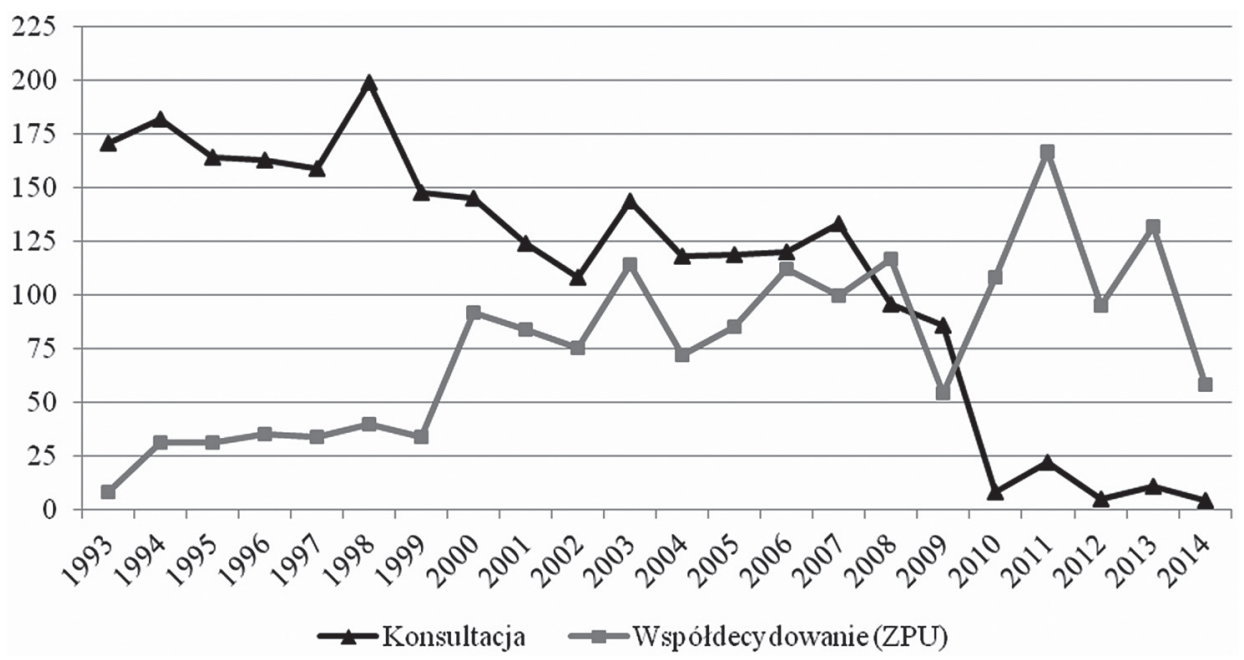

Źródło: F. Häge, The European Union Policy-Making Dataset, „European Union Politics” 2011, Vol. 12, nr 3, s. 455-477, [online] http://dx.doi.org/10.1177/1465116511398739.

Jak już wspomniano, przebieg konsultacji nie jest zdefiniowany w żadnym artykule prawa pierwotnego. W efekcie tryb tej procedury uformował się $w$ ramach nieformalnej praktyki, przy istotnej roli orzecznictwa Trybunału Sprawiedliwości WE/UE. Schemat nr 1 obrazuje przebieg konsultacji wyprowadzony z powyższych źródeł. Najpierw Komisja Europejska opracowuje projekt legislacyjny i przesyła go jednocześnie do Rady i Parlamentu. Jest on następnie poddawany pracom w obu tych instytucjach, po czym Parlament przedstawia opinię zawierającą poprawki. W kolejnym kroku rozpoczynają się kontakty międzyinstytucjonalne. Parlament negocjuje z Komisją, chcąc ją przekonać, aby inkorporowała jego poprawki do projektu (poparcie formalne) lub też broniła ich w późniejszych negocjacjach z Radą (poparcie nieformalne). Po tych rozmowach zmieniona lub pierwotna propozycja legislacyjna jest przesyłana do Rady, która rozpoczyna rozmowy z Komisją nad jej przyjęciem. Po zakończeniu powyższych rozmów Rada podejmuje ostateczną decyzję - albo uchwala projekt bez zmian kwalifikowaną większością głosów (lub jednomyślnie, jeśli taki tryb przewiduje prawo pierwotne), albo modyfikuje go jednomyślnie. Ten drugi krok wynika z art. 293 ust. 1 TFUE, według którego: Jeżeli na mocy Traktatów Rada stanowi na wniosek Komisji, może ona zmienić ten wniosek wytacznie jednomyślnie. Istotą konsultacji jest zatem fakt, że opinia Parlamentu jest niewiążąca dla Rady, przez co ta ostatnia instytucja jest de facto samodzielnym decydentem $\mathrm{w}$ tej procedurze. 
Schemat 1. Przebieg procedury konsultacji

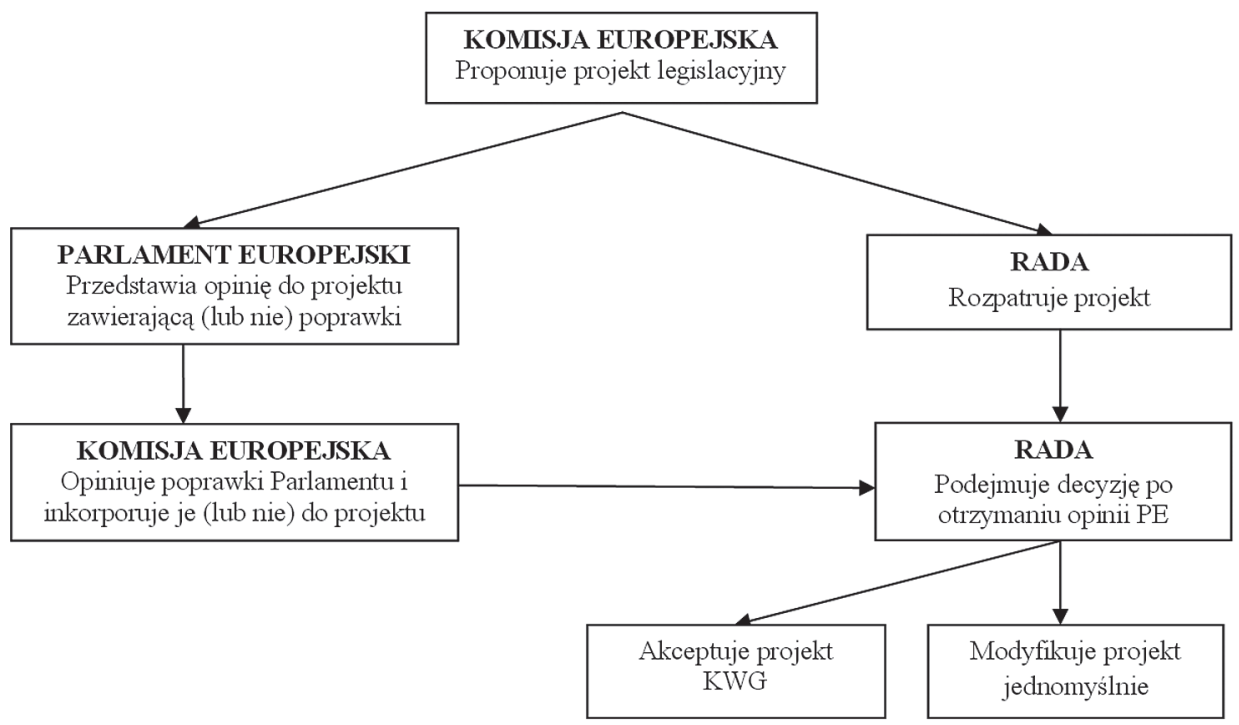

Źródło: opracowanie własne na podstawie A. Kirpsza, Charakterystyka konsultacji jako specjalnej procedury ustawodawczej Unii Europejskiej, „Stosunki Międzynarodowe - International Relations” 2012, Vol. 46, nr 2, s. 112.

\section{HIPOTEZY}

Powyższa charakterystyka konsultacji prowadzi do wniosku, że Parlament Europejski posiada bardzo słabą pozycję formalnoprawną w tej procedurze. Zdaniem niektórych badaczy jest on nawet całkowicie z niej wykluczony, gdyż faktyczne negocjacje toczą się tylko pomiędzy Komisją i Radą ${ }^{1}$ Pojawia się jednak pytanie, czy są jakieś czynniki lub

1 C. Crombez, Legislative Procedures in the European Community, „British Journal of Political Science" 1996, Vol. 26, nr 2, s. 204-205, [online] http://dx.doi.org/10.1017/S0007123400000429; S. Napel, M. Widgrén, Strategic versus Non-strategic Voting Power in the EU Council of Ministers. The Consultation Procedure, „Social Choice and Welfare” 2011, Vol. 37, nr 3, s. 515, [online] http:// dx.doi.org/10.1007/s00355-010-0502-5; R. Scully, The European Parliament and the Co-decision Procedure. A Reassessment, "Journal of Legislative Studies” 1997, Vol. 3, nr 3, s. 60, [online] http:// dx.doi.org/10.1080/13572339708420518; tenże, Policy Influence and Participation in the European Parliament, „Legislative Studies Quarterly” 1997, Vol. 22, nr 2, s. 235, [online] http://dx.doi. org/10.2307/440384; M. Westlake, A Modern Guide to the European Parliament, London 1994, s. 135-137; A. Laruelle, The EU Decision-Making Procedures. Some Insight from Non Co-Operative Game Theory, [w:] Institutional Challenges in the European Union, red. A. van Deemen, M. Widgrén, M. Hösli, London 2002, s. 90, Routledge Advances in European Politics, 6. Zob. też: R. Kardasheva, The Power to Delay. The European Parliament's Influence in the Consultation Procedure, "Journal of Common Market Studies" 2009, Vol. 47, nr 2, s. 392-393; R. Costello, R. Thomson, The Distribution 
techniki negocjacyjne, dzięki którym posłowie mogą przeforsować własne poprawki zgłoszone do projektów konsultacyjnych. Aby na nie odpowiedzieć, zaprojektowano, a następnie przetestowano empirycznie kilka hipotez badawczych.

Pierwsza hipoteza stanowi, że Parlament może liczyć na większy sukces swoich poprawek, jeśli stosuje technikę pakietową. Polega ona na połączeniu negocjacji nad projektem rozpatrywanym $\mathrm{w}$ konsultacji z propozycją(-ami) równocześnie rozstrzyganą(-ymi) w ramach innej formuly legislacyjnej, zwłaszcza w ZPU i w procedurze budżetowej, w których unijna legislatura ma status prawie równoważny Radzie. Parlament może w ten sposób odmówić współpracy z Radą w tej ostatniej procedurze, jeśli ta nie zaakceptuje jego poprawek w konsultacji. W skrajnych przypadkach jest także w stanie zablokować proces legislacyjny w kilku procedurach. Rada musi wówczas uwzględnić przynajmniej niektóre poprawki posłów dotyczące projektu konsultacyjnego, żeby odblokować pozostałe, kluczowe dla jej członków regulacje. Pakietowanie wymusza zatem handel postulatami: Parlament akceptuje roszczenia Rady zgłoszone do projektów uchwalanych w ZPU, w zamian za co Rada aprobuje poprawki posłów dotyczące wniosku konsultacyjnego. Dlatego:

H1: Jeśli Parlament stosuje strategię pakietową, to sukces jego poprawek jest bardziej prawdopodobny.

Drugą techniką pozwalającą Parlamentowi zwiększyć swoją pozycję negocjacyjną w konsultacji jest opóźnianie uchwalenia opinii. Twierdzenie to wynika z faktu, że Traktaty nie przewidują żadnego terminu, w jakim posłowie muszą przedstawić Radzie swoje stanowisko w sprawie projektu. $Z$ tej luki prawnej Trybunał Sprawiedliwości WE wyprowadził w dwóch orzeczeniach w sprawie izoglukozy² zasadę, że Rada nie jest uprawniona do uchwalenia aktu prawnego w konsultacji bez uzyskania opinii Parlamentu, przy czym posłowie nie mogą permanentnie zwlekać z jej przyjęciem, lecz są zobligowani do szczerej współpracy międzyinstytucjonalnej3. To tzw. prawo do opóźniania (power to delay) znacznie wzmocniło pozycję Parlamentu w tej procedu-

of Power Among EU Institutions. Who Wins Under Codecision and Why?, „Journal of European Public Policy” 2013, Vol. 20, nr 7, s. 1032; D. Varela, Just a Lobbyist? The European Parliament and the Consultation Procedure, „European Union Politics” 2009, Vol. 10, nr 1, s. 7-34.

2 Zob.: Judgment of the Court of 29 October 1980 - SA Roquette Frères v Council of the European Communities, Case C-138/79, „European Court Reports” 1980, s. 03333; Judgment of the Court of 29 October 1980 - Maizena GmbH v Council of the European Communities, Case C-139/79, „European Court Reports" 1980, s. 03393. Nazwa wywodzi się stąd, że Trybunał rozpatrywał dwie sprawy jednego dnia, to jest 29 października 1980 r., oraz że dotyczyły one tego samego problemu - izoglukozy.

3 Zob. analizę tych orzeczeń: P. Kapteyn, P. Verloren van Themaat, Introduction to the Law of the European Communities. After the Coming into Force of the Single European Act, Deventer 1990, s. 261; S. Boyron, The Consultation Procedure. Has the Court of Justice Turned against the European Parliament?, „European Law Review” 1996, Vol. 21, s. 145-149; M. O’Neill, European Law - Case C-65/93 and the European Parliament's Right of Consultation. Community Institutional Balance in Action, „Dublin University Law Journal” 1996, Vol. 3, nr 1, s. 149-156; T. Hartley, Consulting the European Parliament, „European Law Review” 1981, Vol. 6, s. 181-185; F. Jacobs, Isoglucose Resurgent. Two Powers of the European Parliament Upheld by the Court, „Common Market Law Review” 1981, Vol. 18, s. 219-226; E. Kirchner, K. Williams, The Legal, Political and Institutional Implications of the Isoglucose Judgments 1980, „Journal of Common Market Studies” 1983, Vol. 22, nr 2, s. 173-190. 
rze $^{4}$. Zamrożenie opinii, a tym samym uniemożliwienie Radzie uchwalenia aktu prawnego, może bowiem doprowadzić do powstania poważnych kosztów ekonomicznych i społecznych dla państw członkowskich. Dotyczy to w szczególności istotnych, dystrybucyjnych i pilnych aktów prawnych. Brak przyjęcia tych regulacji na czas skutkuje niemożnością uruchomienia programów finansowych, np. dla rolników, utratą środków przewidzianych na okres, w którym akt prawny nie mógł być stosowany z powodu opóźnienia, protestami społecznymi czy też powstaniem luk w prawodawstwie. W takich warunkach członkowie Rady stają się bardziej niecierpliwi i skłonni do ustępstw na rzecz Parlamentu. Tylko w ten sposób mogą bowiem odblokować opinię, uchwalić akt prawny i uniknąć negatywnych konsekwencji. Stąd:

H2: Jeśli Parlament opóźnia uchwalenie opinii, to sukces jego poprawek jest bardziej prawdopodobny.

Kolejnym czynnikiem, który powinien wpływać na sukces poprawek Parlamentu, jest poparcie Komisji. Jak już wspomniano w poprzedniej części, Komisja może akceptować roszczenia Parlamentu w dwojaki sposób: formalnie lub nieformalnie. W pierwszym przypadku inkorporuje poprawki posłów do swojego projektu. Następnie tak zmodyfikowany wniosek przedstawia Radzie, która uchwala go, co do zasady, kwalifikowaną większością głosów albo zmienia jednomyślnie (vide art. 293 ust. 1 TFUE). Oznacza to, że ministrowie mogą odrzucić poprawki Parlamentu tylko według trudniejszej do osiągnięcia zasady głosowania, co zwiększa szansę ich przyjęcia. Znaczenie formalnego poparcia jest podkreślane przede wszystkim przez racjonalistów, gdyż zakładają oni ograniczający wpływ norm formalnoprawnych na proces decyzyjny ${ }^{5}$.

Natomiast nieformalne poparcie Komisji polega na akceptacji poszczególnych poprawek posłów bez ich wprowadzania do projektu, lecz w oparciu o zobowiązanie do ich ustnej obrony w czasie późniejszych negocjacji tej instytucji z Radą. Z perspektywy konstruktywistycznej taki sposób opiniowania powinien pozytywnie wpływać na sukces postulatów Parlamentu ze względu na obecność w relacjach między Radą i Komisją kooperacyjnego kontekstu normatywnego. Kontakty między członkami tych dwóch instytucji są częste, regularne, tajne, wieloaspektowe materialnie, intensywne normatywnie i mało upolitycznione, a więc spełniają wszystkie warunki determinujące socjalizację i kooperacyjne negocjacje w formie rozwiązywania problemów lub deliberacji ${ }^{6}$. Ponadto badania empiryczne dowiodty, że przedstawiciele Komisji są w Radzie niezwy-

R. Kardasheva, The Power to Delay..., s. 385; G. Tsebelis, G. Garrett, The Institutional Foundations of Intergovernmentalism and Supranationalism in the European Union, „International Organization” 2001, Vol. 55, nr 2, s. 372; R. Scully, Policy Influence..., s. 235.

5 C. Crombez, Legislative Procedures..., s. 212-214; G. Tsebelis, G. Garrett, Legislative Politics in the EU, „European Union Politics” 2000, Vol. 1, nr 1, s. 9-36; ciż, The Institutional Foundations..., s. 374.

6 J. Lewis, The Janus Face of Brussels. Socialization and Everyday Decision Making in the European Union, „International Organization” 2005, Vol. 59, nr 4, s. 945-948; tenże, How Institutional Environments Facilitate Co-Operative Negotiation Styles in EU Decision-Making, , Journal of European Public Policy” 2010, Vol. 17, nr 5, s. 648-664, [online] http://dx.doi.org/10.1080/13501761003748591; J. Checkel, International Institutions and Socialization in Europe. Introduction and Framework, „International Organization" 2005, Vol. 59, nr 4, s. 808-816. 
kle cenieni i darzeni zaufaniem, a ich stanowisko jest zawsze brane pod uwagę ${ }^{7}$. Komisja posiada zatem duży potencjał transformujący preferencje członków Rady na niższych szczeblach, a dzięki deliberacji jest w stanie przekonać reprezentantów rządowych do zmiany ich stanowisk. Jeśli zatem występuje w negocjacjach z Radą jako adwokat Parlamentu, to jest duże prawdopodobieństwo, że zwiększy szanse inkorporacji jego poprawek do finalnej wersji aktu prawnego. Dlatego:

H3: Sukces poprawek Parlamentu jest bardziej prawdopodobny, jeśli są one popierane przez Komisję.

Kolejnym czynnikiem, który powinien wpływać na większy sukces Parlamentu, jest bliskość końca kadencji PE. Twierdzenie to wynika z założeń teorii organizacji funkcjonującej w obrębie konstruktywizmu społecznego ${ }^{8}$. Zgodnie z nią, gdy instytucje negocjują projekty w okresie bliskim końca kadencji, ich członkowie powinni odczuwać tzw. stres organizacyjny, czyli sytuację generującą fizyczne lub psychologiczne oczekiwania wobec osoby i powodującą jej anormalne działanie 9 . Stres jest rezultatem obawy, że w wyniku nadchodzących wyborów do Parlamentu dojdzie do istotnych przeobrażeń procesu podejmowania decyzji wynikających ze zmiany składu czy konfiguracji grup politycznych $\mathrm{w}$ tej instytucji, ale także $\mathrm{z}$ wprowadzenia reform instytucjonalnych (np. przeniesienie negocjowanego projektu z konsultacji do ZPU). Te zmiany mogą skutkować przeciągnięciem się w czasie uchwalenia niektórych aktów prawnych oraz otwarciem na nowo negocjacji w sprawie projektów prawie rozstrzygniętych w poprzedniej kadencji. W warunkach konsultacji powyższy stres powinien w szczególności dotyczyć Rady, która posiada w niej dominującą pozycję. Jej członkowie mogą być zatem zdeterminowani, aby jak najwięcej negocjacji legislacyjnych sfinalizować jeszcze przed końcem kadencji ${ }^{10}$. W tym celu Rada powinna być bardziej chętna do ustępstw na rzecz Parlamentu w zamian za szybkie procedowanie ze strony posłów. Stąd:

H4: Sukces poprawek Parlamentu jest bardziej prawdopodobny, gdy projekt jest negocjowany w okresie bliskim końca kadencji PE.

W świetle założeń racjonalizmu kluczową rolę w negocjacjach odgrywają posiadane przez aktorów zasoby informacyjne, instytucjonalne, czasowe oraz koordynacyjne. To one określają ich pozycję startową oraz decydują o wyborze najlepszych technik

M. Egeberg, Transcending Intergovernmentalism? Identity and Role Perceptions of National Officials in EU Decision-Making, "Journal of European Public Policy” 1999, Vol. 6, nr 3, s. 468-469. Zob. także: A. Rasmussen, The Role of the European Commission in Co-decision. A Strategic Facilitator Operating in a Situation of Structural Disadvantage, „European Integration online Papers” 2003, Vol. 7, nr 10, s. 8-9.

8 C. Perrow, Organizational Analysis. A Sociological View, Belmont, Calif. 1970, Behavioral Science in Industry Series; The New Institutionalism in Organizational Analysis, red. W. Powell, P. DiMaggio, Chicago 1991.

9 Zob. np.: C. Cooper, Theories of Organizational Stress, Oxford-New York 1998.

10 D. Leuffen, R. Hertz, If Things Can Only Get Worse. Anticipation of Enlargement in the European Union, „European Journal of Political Research” 2010, Vol. 49, nr 1, s. 53-74; R. Hertz, D. Leuffen, Gridlock after Enlargement? An Analysis of Legislative Output in the European Union, paper presented at EUSA conference, Los Angeles, CA, 23-25 IV 2009. 
negocjacyjnych ${ }^{11}$. Z perspektywy Parlamentu presja na te zasoby w konsultacji jest szczególnie silna. Można to uzasadnić trzema argumentami. Po pierwsze posłowie dysponują $\mathrm{w}$ tej procedurze skąpymi informacjami na temat zarówno stanowiska członków Rady, jak i przebiegu oraz efektów toczących się w niej negocjacji. Jest to spowodowane brakiem tzw. trilogów, czyli nieformalnych kontaktów między reprezentantami obu instytucji ${ }^{12}$. W rezultacie deputowani mają problem $\mathrm{z}$ wyborem odpowiedniej strategii negocjacyjnej. Po drugie Parlament posiada w konsultacji niewielkie uprawnienia instytucjonalne, dlatego za każdym razem musi poszukiwać instrumentów działania, które wzmacniałyby jego pozycję negocjacyjną. To z kolei wymaga dużych zasobów (np. przekonania większości posłów do opóźnienia czy pakietowania). Po trzecie liczba projektów rozstrzyganych w konsultacji w latach 1999-2009 była bardzo wyso$\mathrm{ka}^{13}$. Oznacza to, że zarządzanie negocjacjami w sprawie tak wielu regulacji generowało w tym czasie wysokie koszty koordynacyjne. Poza tym w porównaniu do Rady Parlamentowi jest trudniej konstruować wewnętrzne stanowisko legislacyjne. O ile w Radzie jest ono wypracowywane w sposób tajny i w gronie zaledwie 28 członków, o tyle w Parlamencie należy połączyć ze sobą interesy 751 posłów, wielu frakcji narodowych i politycznych oraz grup społecznych. Dlatego w warunkach ograniczonych zasobów i silnej presji na nie Parlament powinien kumulować swoje wysiłki na negocjowaniu tylko tych projektów konsultacyjnych, które są najważniejsze z punktu widzenia jego tożsamości i interesów ${ }^{14}$. I z racji szczególnej koncentracji swoich zasobów powinien on być bardziej skuteczny przy rozstrzyganiu właśnie takich regulacji. Stąd:

11 A. Warntjen, Between Bargaining and Deliberation. Decision-making in the Council of the European Union, "Journal of European Public Policy" 2010, Vol. 17, nr 5, s. 667; S. Bailer, What Factors Determine Bargaining Power and Success in EU Negotiations?, "Journal of European Public Policy" 2010, Vol. 17, nr 5, s. 743-757, [online] http://dx.doi.org/10.1080/13501761003748765; S. Bailer, G. Schneider, Nash versus Schelling? The Importance of Constraints in Legislative Bargaining, [w:] The European Union Decides, red. R. Thomson i in., Cambridge 2006, s. 153-177, Political Economy of Institutions and Decisions; A. Dür, G. Mateo, Bargaining Power and Negotiation Tactics. The Negotiations on the EU's Financial Perspective, 2007-2013, "Journal of Common Market Studies” 2010, Vol. 48, nr 3, s. 561-562.

12 Więcej o trilogach zob.: H. Farrell, A. Héritier, Interorganizational Negotiation and Intraorganizational Power in Shared Decision Making. Early Agreements Under Codecision and Their Impact on the European Parliament and Council, „Comparative Political Studies” 2004, Vol. 37, nr 10, s. 1184-1212; A. Kirpsza, Analiza zjawiska wczesnych nieformalnych porozumień legislacyjnych w zwyktej procedurze ustawodawczej, „Studia Europejskie” 2013, nr 4, s. 101-132; A. Rasmussen, C. Reh, The Consequences of Concluding Codecision Early. Trilogues and Intra-Institutional Bargaining Success, "Journal of European Public Policy" 2013, Vol. 20, nr 7, s. 1006-1024; M. Shackleton, The Politics of Codecision, „Journal Common Market Studies” 2000, Vol. 38, nr 2, s. 334; M. Shackleton, T. Raunio, Codecision since Amsterdam. A Laboratory for Institutional Innovation and Change, "Journal of European Public Policy" 2003, Vol. 10, nr 2, s. 177, 181; C. Reh, Is Informal Politics Undemocratic? Trilogues, Early Agreements and the Selection Model of Representation, "Journal of European Public Policy" 2014, Vol. 21, nr 6, s. 822-841, [online] http://dx.doi.org/10.1080/13501763.2014.910247.

13 Ogółem w latach 1999-2009 uchwalono w konsultacji 1198 aktów prawnych, a we współdecydowaniu - 711 .

14 A. Ripoll Servent, Playing the Co-Decision Game? Rules' Changes and Institutional Adaptation at the LIBE Committee, „Journal of European Integration” 2012, Vol. 34, nr 1, s. 59. 
H5: Sukces poprawek Parlamentu jest bardziej prawdopodobny, jeśli projekt jest szczególnie ważny dla UE.

W literaturze racjonalistycznej przyjmuje się, że aktorzy powinni adoptować bardziej konfliktowe strategie negocjacyjne w odniesieniu do kwestii, które sq ważne dla ich interesów $w^{15}$. Kumulują wówczas wszystkie swoje zasoby i działania, aby osiągnąć w tych materiach rozwiązania w pełni ich satysfakcjonujące. Z punktu widzenia członków Rady takimi ważnymi kwestiami są sprawy finansowe, w szczególności redystrybucyjne ${ }^{16}$. Należą one do sfery spraw o sumie zerowej (zero-sum issues), w których jedni wygrywają kosztem drugich ${ }^{17}$. Przekazanie większych środków na poziom wspólnotowy powoduje bowiem ich utratę przez poszczególne, zwłaszcza najbogatsze, państwa członkowskie. W literaturze podnosi się również, że sprawy redystrybucyjne i o sumie zerowej generują szczególnie konfliktowe zachowania i strategie ${ }^{18}$. Dlatego można przypuszczać, że gdy Parlament zgłasza do projektu konsultacyjnego poprawki finansowe, które są przeważnie sprzeczne z interesami państw, członkowie Rady za wszelką cenę dążą do ich odrzucenia. W efekcie poziom sukcesu takich modyfikacji powinien być bardzo niski ${ }^{19}$. Stąd:

H6: Jeśli Parlament zgłasza poprawki dotyczące spraw finansowych, to ich sukces jest mniej prawdopodobny.

Natomiast z punktu widzenia Parlamentu szczególnie ważnymi kwestiami są prawa człowieka i demokracja. Ich istotne znaczenie wynika endogenicznie z tożsamości tej instytucji. Parlament Europejski jest powszechnie postrzegany jako emanacja demokracji oraz strażnik praw człowieka w UE. Świadczą o tym chociażby sondaże, obecność w strukturze tej instytucji specjalnej Podkomisji ds. Praw Człowieka (DROI), organizacja licznych misji obserwacji wyborów, możliwość składania petycji do PE (art. 227 TFUE) czy liczne przyznawane nagrody (im. Sacharowa, Europejska Nagroda Obywatelska, LUX Prize). Z jednej strony obywatele UE oczekują, że Parlament będzie wszelkimi środkami bronił demokracji i praw człowieka, z drugiej zaś kwestie te przeważnie nie generują dodatkowych kosztów dla państw członkowskich oraz nie podmywają ich pozycji instytucjonalnej w UE, dlatego nie powinny być przedmiotem uporczywej kontestacji z ich strony. Można zatem przypuszczać, że w przypadku poprawek demokratycznych i praw człowieka Parlament będzie mimo ograniczonej pozycji w konsul-

15 H.E. McKibben, Issue Characteristics, Issue Linkage, and States' Choice of Bargaining Strategies in the European Union, „Journal of European Public Policy” 2010, Vol. 17, nr 5, s. 698-699.

16 T. Lowi, Four Systems of Policy, Politics and Choice, „Public Administration Review” 1972, Vol. 32, nr 4, s. 298-310, [online] http://dx.doi.org/10.2307/974990.

17 H. Raiffa, The Art and Science of Negotiation, Cambridge, Mass. 1982, s. 33.

18 H. McKibben, Issue Characteristics..., s. 698; O. Elgström, C. Jönsson, Negotiation in the European Union. Bargaining or Problem-Solving?, „Journal of European Public Policy” 2000, Vol. 7, nr 5, s. 694.

19 Zob.: C. Burns, Who Pays? Who gains? How do Costs and Benefits Shape the Policy Influence of the European Parliament, "Journal of Common Market Studies” 2005, Vol. 43, nr 3, s. 492-493; M. Shackleton, The Politics of Codecision, s. 338; D. Judge, D. Earnshaw, C. Ngaire, Ripples or Waves. The European Parliament in the European Community Policy Process, „Journal of European Public Policy" 1994, Vol. 1, nr 1, s. 27-52. 
tacji szczególnie walczyć o ich rozstrzygnięcie na swoją korzyść, przy mniejszej skłonności Rady do obstrukcji. Ta determinacja posłów powinna prowadzić do większego sukcesu takich modyfikacji. Stąd:

H7: Jeśli Parlament zgłasza poprawki z zakresu demokracji i praw człowieka, to ich sukces jest bardziej prawdopodobny.

\section{METODA WERYFIKACJI HIPOTEZ}

Powyższe hipotezy postanowiono zweryfikować w sposób ilościowy za pomocą regresji logistycznej. W pierwszym kroku zaprojektowano zmienne. Najpierw skonstruowano binarną zmienną zależną o nazwie „Sukces poprawek PE”, która wynosi 1, jeśli zgłoszona przez posłów poprawka została inkorporowana do finalnej wersji aktu prawnego, albo 0 , gdy była przez Radę odrzucona i nie znalazła się w końcowej regulacji. Co istotne, poprawkę zdefiniowano zgodnie z metodologią postulatów (issue-based approach $)^{20}$ jako modyfikację projektu spełniającą trzy warunki. Po pierwsze była zasadnicza, merytoryczna i proponowała zmianę kluczowych założeń projektu. Poprawki techniczne czy propagandowe nie zostały zatem uwzględnione w badaniu. Po drugie była konfliktowa, a więc stanowiła istotny punkt sporny w negocjacjach między Parlamentem i Radą. W rozprawie nie wzięto zatem pod uwagę roszczeń posłów, które co prawda żądały modyfikacji istotnych założeń projektu, ale nie były kontestowane przez Radę. Po trzecie poprawkę zdefiniowano nie jako każdą formalną modyfikację zgłoszoną do projektu, lecz jako postulat merytoryczny, czyli zbiór modyfikacji dotyczących tej samej kwestii. Inaczej mówiąc, kilka jednakowych lub podnoszących ten sam problem (postulat) modyfikacji formalnych było traktowanych jako jedna poprawka. I vice ver$s a$, z jednej modyfikacji formalnej mogło być wyprowadzonych kilka poprawek (postulatów), jeśli dotykała ona wielu istotnych i spornych kwestii.

Następnie zoperacjonalizowano kilka zmiennych niezależnych odpowiadających czynnikom zawartym w hipotezach. I tak, $H 1$ jest weryfikowana za pomocą zmiennej binarnej o nazwie „Pakietowanie”. Wynosi ona 1, gdy Parlament zablokował postępowanie legislacyjne w ZPU lub procedurze budżetowej, żądając akceptacji przez Radę jego poprawek przedstawionych w konsultacji, lub gdy Komisja przedstawiła pakiet kilkuprojektowy składający się z powiązanych ze sobą wniosków rozpatrywanych jednocześnie w ZPU i konsultacji, albo 0, gdy posłowie nie zastosowali powyższej techniki lub gdy Komisja nie przedstawiła takiego pakietu. $\mathrm{H} 2$ jest testowana za pomocą zmiennej dychotomicznej o nazwie „Opóźnienie”. Jest ona równa 1, jeśli Parlament opóźnił przyjęcie swojej opinii, albo 0 , gdy takiej strategii nie zastosowat. W celu weryfikacji $\mathrm{H3}$ skonstruowano zmienną dychotomiczną „Poparcie Komisji”, która wynosi 1, jeśli Komi-

20 Zob.: The European Union Decides...; H.E. McKibben, Issue Characteristics..., s. 694-707; R. Thomson, J. Boerefijn, F. Stokman, Actor alignments in European Union decision making, Actor Alignments in European Union Decision Making, „European Journal of Political Research” 2004, Vol. 43, nr 2, s. 237 -262, [online] http://dx.doi.org/10.1111/j.1475-6765.2004.00153.x; R. Costello, R. Thomson, The Distribution of Power..., s. 1025-1039; R. Kardasheva, The Power to Delay..., s. 395. 
sja zaakceptowała formalnie lub nieformalnie daną poprawkę Parlamentu, albo 0, gdy nie poparła roszczenia posłów. $H 4$ jest testowana przez zmienną dychotomiczną „Koniec kadencji PE”. Jest ona równa 1 , gdy akt prawny został uchwalony na sześć miesięcy przed końcem piątej (1999-2004) lub szóstej (2004-2009) kadencji Parlamentu, to jest między 1 grudnia 2003 r. a 1 czerwca 2004 r. oraz 1 grudnia 2008 r. a 1 czerwca 2009 r. ${ }^{21}$, albo 0 , gdy został przyjęty w innym okresie. H5 jest sprawdzana przez zmienną ilościowa ciągłą o nazwie „Ważność”. Odzwierciedla ona liczbę motywów znajdujących się na początku uchwalonego w konsultacji aktu prawnego ${ }^{22}$. Im więcej motywów zawierała dana regulacja, tym była ważniejsza. $H 6$ i $H 7$ są testowane przez zmienną nominalną czterowartościową „Materia poprawki”23. Wynosi ona 1, gdy posłowie zgłosili w czasie negocjacji poprawkę dotyczącą założeń lub materii projektu („Poprawka materialna”) ${ }^{24}$, 2 - gdy poprawka dotyczyła spraw finansowych i budżetowych („Poprawka finansowa”) ${ }^{25}, 3$ - gdy tyczyła się demokracji i praw człowieka („Poprawka demokratyczna”) ${ }^{26}$, lub 4 - gdy obejmowała kompetencje instytucjonalne Parlamentu („Poprawka instytucjonalna”) ${ }^{27}$. Za kategorię referencyjną (porównawczą) przyjęto „Poprawkę materialną”.

Powyższe predyktory uzupełniono o cztery zmienne kontrolne. Ich zadaniem jest sprawdzenie, czy zasada głosowania w Radzie, forma aktu prawnego oraz doświadczenie i afiliacja polityczna sprawozdawcy nie wywierają widocznego wpływu na związki między zmienną zależną a zmiennymi niezależnymi przewidziane w hipotezach. I tak, pierwszym predyktorem kontrolnym jest „Zasada głosowania w Radzie”. Ma on wartość dychotomiczną i wynosi 1 , jeśli akt prawny był przyjęty przez Radę kwalifikowaną większością głosów, albo 0 , gdy przeszedł jednomyślnie ${ }^{28}$. Druga zmienna kontrolna „Dyrektywa” - ma postać binarną i przyjmuje wartość 1 , jeżeli analizowany projekt był

21 Choć wybory do Parlamentu Europejskiego odbyły się 10-13 czerwca 2004 r. i 4-7 czerwca 2009 r., to za koniec obu kadencji przyjęto początek tego miesiąca, gdyż w okresie przedwyborczym aktywność legislacyjna posłów prawie nie istniała.

22 Taką metodę operacjonalizacji ważności stosują m.in.: R. Kardasheva, The Power to Delay..., s. 398; F. Häge, Committee Decision-making in the Council of the European Union, „European Union Politics” 2007, Vol. 8, nr 3, s. 315, [online] http://dx.doi.org/10.1177/1465116507079539; C. Reh i in., The Informal Politics of Legislation. Explaining Secluded Decision Making in the European Union, „Comparative Political Studies" 2011, Vol. 46, nr 9, s. 1127.

23 Zob.: R. Kardasheva, The Power to Delay..., s. 405-406.

24 Np. poprawki zwiększające lub limitujące obszar, czas i zakres stosowania projektu czy wprowadzające definicje i klauzule zmieniające istotę regulacji.

25 Np. poprawki dotyczące wydatkowania pieniędzy, finansowania programów, zmiany budżetów czy tworzenia nowych funduszy.

26 Np. poprawki dotyczące demokratyzacji regionów pozaunijnych, ochrony danych osobowych, azylu, roli policji czy wprowadzające odwołania do konwencji praw człowieka.

27 Np. poprawki kontestujące dany sposób podejmowania decyzji, ustanawiające bardziej korzystne dla posłów procedury tworzenia prawodawstwa (np. zmiana konsultacji na współdecydowanie), wprowadzające do aktu prawnego klauzule komitologiczne (np. zmiana procedury doradczej na regulacyjną połączoną z kontrolą) czy zobowiązujące Radę i Komisję do informowania Parlamentu o swojej dziatalności w danej sferze.

28 Chodzi tu nie o faktyczny wynik głosowania, lecz o podstawę prawno-traktatową przewidującą określoną procedurę głosowania w Radzie w sprawie danego projektu. 
dyrektywą, albo 0 , jeśli miał formą rozporządzenia, decyzji lub decyzji ramowej. Trzecim predyktorem kontrolnym jest zmienna ilościowa ciągła o nazwie „Doświadczenie sprawozdawcy". Odpowiada ona liczbie lat pełnienia przez sprawozdawcę funkcji posła do Parlamentu Europejskiego, licząc od roku rozpoczęcia mandatu do roku przyjęcia opinii przez tę instytucję. Jako czwartą zmienną kontrolną zaprojektowano predyktor nominalny „Duże grupy polityczne”. Wynosi on 1, gdy sprawozdawcą projektu był poseł należący do EPP-ED ${ }^{29}, 2$ - jeśli sprawozdawcą był członek PES 30,3 - jeśli sprawozdawca należał do ELDR/ALDE ${ }^{31}$, albo 0 , jeśli sprawozdawcą był deputowany niezrzeszony lub należący do pozostałych frakcji działających w Parlamencie w latach 1999-2009, a więc: G/EFA ${ }^{32}$, GUE/NGL ${ }^{33}, \mathrm{UEN}^{34}$, TGI ${ }^{35}$, IND/DEM ${ }^{36}$ i ITS $^{37}$. Ostatnią kategorię przyjęto za referencyjną. Tabela nr 1 zawiera pełne kodowanie powyższych zmiennych wraz ze źródłem informacji na ich temat.

Tabela 1. Operacjonalizacja zmiennych niezależnych

\begin{tabular}{|c|c|c|c|c|}
\hline $\mathrm{Nr}$ & $\begin{array}{c}\text { Nazwa } \\
\text { zmiennej }\end{array}$ & Kodowanie zmiennej niezależnej & Źródło & $\begin{array}{l}\text { Przewidy- } \\
\text { wany efekt }\end{array}$ \\
\hline $\mathrm{H} 1$ & $\begin{array}{l}\text { Pakieto- } \\
\text { wanie }\end{array}$ & $\begin{array}{l}1 \text { - Parlament zastosował strategię pakietową lub roz- } \\
\text { strzygany projekt znajdował się w pakiecie kilkupro- } \\
\text { jektowym zaproponowanym przez Komisję; } \\
0 \text { - Parlament nie zastosował strategii pakietowej lub } \\
\text { brak pakietu kilkuprojektowego }\end{array}$ & $\begin{array}{l}\text { OEIL, Rejestr } \\
\text { Publiczny Rady }\end{array}$ & + \\
\hline $\mathrm{H} 2$ & $\begin{array}{l}\text { Opóź- } \\
\text { nienie }\end{array}$ & $\begin{array}{l}1 \text { - Parlament opóźnił przyjęcie opinii dotyczącej } \\
\text { projektu; } \\
0 \text { - brak opóźnienia }\end{array}$ & OEIL & + \\
\hline $\mathrm{H} 3$ & $\begin{array}{l}\text { Poparcie } \\
\text { Komisji }\end{array}$ & $\begin{array}{l}1 \text { - Komisja poparła poprawkę Parlamentu; } \\
0 \text { - brak poparcia poprawki przez Komisję }\end{array}$ & $\begin{array}{l}\text { Baza Posiedzeń } \\
\text { Plenarnych } \\
\text { Parlamentu, } \\
\text { OEIL, PreLex }\end{array}$ & + \\
\hline $\mathrm{H} 4$ & $\begin{array}{l}\text { Koniec } \\
\text { kadencji } \\
\text { PE }\end{array}$ & $\begin{array}{l}1 \text { - akt prawny został uchwalony na } 6 \text { miesięcy przed } \\
\text { końcem piątej (1999-2004) lub szóstej (2004-2009) ka- } \\
\text { dencji PE, to jest między } 1 \text { grudnia } 2003 \text { r. a } 1 \text { czerwca } \\
2004 \text { r. oraz } 1 \text { grudnia } 2008 \text { r. a } 1 \text { czerwca } 2009 \text { r.; } \\
0 \text { - akt prawny został przyjęty w innym okresie }\end{array}$ & OEIL & + \\
\hline
\end{tabular}

29 Grupa Europejskiej Partii Ludowej (Chrześcijańskich Demokratów) - Europejskich Demokratów.

30 Grupa Partii Europejskich Socjalistów (1999-2004); Grupa Socjalistyczna w Parlamencie Europejskim (2004-2009).

31 Grupa Partii Europejskich Liberałów, Demokratów i Reformatorów (1999-2004); Grupa Porozumienia Liberałów i Demokratów na rzecz Europy (2004-2009).

32 Grupa Zielonych/Wolnego Sojuszu Europejskiego.

33 Grupa Zjednoczonej Lewicy Europejskiej - Zielonej Lewicy Nordyckiej.

34 Unia na rzecz Europy Narodów.

35 Techniczna Grupa Niezależnych Posłów (1999-2001).

36 Niepodległość i Demokracja (2004-2009).

37 Tożsamość, Tradycja, Suwerenność (2007). 


\begin{tabular}{|c|c|c|c|c|}
\hline $\mathrm{Nr}$ & $\begin{array}{c}\text { Nazwa } \\
\text { zmiennej }\end{array}$ & Kodowanie zmiennej niezależnej & Źródło & $\begin{array}{l}\text { Przewidy- } \\
\text { wany efekt }\end{array}$ \\
\hline $\mathrm{H} 5$ & Ważność & $\begin{array}{l}\text { Liczba motywów umieszczona na początku uchwalo- } \\
\text { nego aktu prawnego }\end{array}$ & Eur-Lex & + \\
\hline $\begin{array}{l}\mathrm{H} 6 \\
\text { i H7 }\end{array}$ & $\begin{array}{c}\text { Materia } \\
\text { poprawek }\end{array}$ & $\begin{array}{l}1 \text { - poprawka dotycząca założeń lub materii projektu } \\
\text { („Poprawka materialna”); } \\
2 \text { - poprawka dotycząca finansów i budżetu } \\
\text { („Poprawka finansowa”); } \\
3 \text { - poprawka dotycząca demokracji i praw człowieka } \\
\text { („Poprawka demokratyczna”); } \\
\text { 4- poprawka dotycząca kompetencji instytucjonal- } \\
\text { nych Parlamentu („Poprawka instytucjonalna”) }\end{array}$ & $\begin{array}{l}\text { OEIL, Baza } \\
\text { Posiedzeń } \\
\text { Plenarnych } \\
\text { Parlamentu, } \\
\text { Rejestr } \\
\text { Publiczny Rady }\end{array}$ & $\begin{array}{l}-(H 6) \\
+(H 7)\end{array}$ \\
\hline $\mathrm{K} 1$ & $\begin{array}{l}\text { Zasada } \\
\text { głoso- } \\
\text { wania } \\
\text { w Radzie }\end{array}$ & $\begin{array}{l}1 \text { - akt prawny został przyjęty w Radzie kwalifikowa- } \\
\text { ną większością głosów; } \\
0 \text { - akt prawny został przyjęty w Radzie w procedurze } \\
\text { jednomyślności }\end{array}$ & $\begin{array}{l}\text { Rejestr } \\
\text { Publiczny } \\
\text { Rady, Eur-Lex }\end{array}$ & 0 \\
\hline K2 & $\begin{array}{l}\text { Dyrek- } \\
\text { tywa }\end{array}$ & $\begin{array}{l}1 \text { - uchwalony akt prawny miał formę dyrektywy; } \\
0 \text { - uchwalony akt prawny był rozporządzeniem, decy- } \\
\text { zją lub decyzją ramową }\end{array}$ & $\begin{array}{l}\text { Eur-Lex, } \\
\text { PreLex }\end{array}$ & 0 \\
\hline K3 & $\begin{array}{l}\text { Doświad- } \\
\text { czenie } \\
\text { sprawo- } \\
\text { zdawcy }\end{array}$ & $\begin{array}{l}\text { Wyrażony w latach okres pełnienia przez sprawoz- } \\
\text { dawcę analizowanego projektu mandatu posła do } \\
\text { Parlamentu Europejskiego, licząc od roku rozpoczę- } \\
\text { cia mandatu do roku uchwalenia opinii w sprawie } \\
\text { projektu }\end{array}$ & $\begin{array}{l}\text { strona in- } \\
\text { ternetowa } \\
\text { Parlamentu } \\
\text { Europejskiego }\end{array}$ & 0 \\
\hline K4 & $\begin{array}{l}\text { Duże } \\
\text { grupy } \\
\text { polityczne }\end{array}$ & $\begin{array}{l}1 \text { - sprawozdawca był posłem należącym do EPP-ED; } \\
2 \text { - sprawozdawca był członkiem PES; } \\
3 \text { - sprawozdawca był członkiem ELDR/ALDE; } \\
0 \text { - sprawozdawca był niezrzeszony lub należał do } \\
\text { innej frakcji (G/EFA, UEN, GUE/NGL, ITS, TDI, } \\
\text { IND/DEM) }\end{array}$ & $\begin{array}{l}\text { OEIL, strona } \\
\text { internetowa } \\
\text { Parlamentu } \\
\text { Europejskiego }\end{array}$ & 0 \\
\hline
\end{tabular}

W kolejnym kroku zbudowano bazę danych, na której przeprowadzono statystyczny test hipotez. Składa się ona ze wszystkich aktów prawnych UE, które spełniają cztery warunki: po pierwsze zostały uchwalone w trakcie piątej i szóstej kadencji PE, czyli w latach 1999-2009, po drugie były przyjęte w procedurze konsultacji, po trzecie miały formę rozporządzenia, dyrektywy, decyzji lub decyzji ramowej, po czwarte Parlament zgłosił do nich co najmniej jedną poprawkę. W ten sposób zidentyfikowano 599 projektów, które utworzyły próbę badawczą.

Następnie na powyższej bazie danych (próbie) przeprowadzono właściwy test hipotez w oparciu o regresję logistyczną ${ }^{38}$. Jest to metoda statystyczna, którą stosuje się, gdy zmienna zależna ma rozkład binarny (0 albo 1 ), a więc taki jak w niniejszym badaniu. Regresję logistyczną można opisać następującym wzorem:

38 Więcej zob.: A. Kirpsza, Zastosowanie regresji logistycznej w studiach nad Unia Europejska, [w:] Metody jakościowe i ilościowe w badaniu organizacji i dziatania Unii Europejskiej, red. K. Ławniczak, Warszawa 2013; D. Hosmer, S. Lemeshow, Applied Logistic Regression, New York 2000; S. Menard, Applied Logistic Regression, Thousand Oaks 2002. 


$$
P(Y=1)=\frac{e^{\operatorname{logit}(p)}}{1+e^{\log i t(p)}}=\frac{1}{1+e^{-\log i t(p)}}=\frac{1}{1+e^{-\left(\beta_{0}+\beta_{1} X_{1}+\ldots+\beta_{k} X_{k}\right)}}
$$

gdzie:

$P(Y=1)$ - prawdopodobieństwo, że $Y$ będzie równe 1;

$e-$ stała Eulera $=2,71828$, baza logarytmu naturalnego;

logit - funkcja przekształcająca prawdopodobieństwo na logarytm szansy ${ }^{39}$;

$\beta_{o}-$ wyraz wolny (intercept, stała), punkt przecięcia z osią $Y$, gdy $X=0$;

$\beta_{k}$ - współczynniki kierunkowe nachylenia linii regresji;

$k$ - kolejne zmienne niezależne.

Regresja logistyczna pozwala oszacować prawdopodobieństwo (szansę) zajścia zdarzenia $Y$ przy określonym wpływie czynników $X$. Inaczej mówiąc, informuje, czy i jak wzrost lub spadek zmiennych niezależnych $(X)$ przekłada się na wzrost lub spadek prawdopodobieństwa wystąpienia zdarzenia zawartego w zmiennej zależnej $(Y=1)$. W ramach tej metody wylicza się również tzw. ilorazy szans $\left(O R-o d d s \text { ratio, } \exp ^{(\beta)}\right)^{40}$. Informują one, jak zmienia się szansa zajścia zdarzenia zawartego w zmiennej zależnej $Y$ (wartość 1 ) w grupie obserwacji $A$ w porównaniu do innej grupy $B$, przy utrzymaniu pozostałych predyktorów na stałym poziomie (ceteris paribus). Postać matematyczna $O R$ jest następująca:

$$
O R=\frac{O(A)}{O(B)}=\frac{P(A)}{1-P(A)}: \frac{P(B)}{1-P(B)}
$$

gdzie:

$A$ - grupa obserwacji A (np. mężczyźni, kategoria lub jednostka zmiennej niezależnej); $B$ - grupa obserwacji B (np. kobiety, kategoria lub jednostka zmiennej niezależnej); $O(A)-$ szansa $^{41}$ zajścia zdarzenia $Y$ (wartość $1 \mathrm{w}$ zmiennej zależnej) w grupie $A$; $O(B)$ - szansa zajścia zdarzenia $Y$ (wartość 1 w zmiennej zależnej) w grupie $B$; $P(A)$ - prawdopodobieństwo zajścia zdarzenia $Y$ (wartość 1 w zmiennej zależnej) w grupie $A$;

$P(B)$ - prawdopodobieństwo zajścia zdarzenia $Y$ (wartość 1 w zmiennej zależnej) w grupie $B$.

Weryfikację hipotez za pomocą regresji logistycznej dokonano na dwóch modelach. Model nr 1 zawiera zmienne odpowiadające wyłącznie hipotezom H1-H7. Model nr 2

39 Logit ma następującą postać:

$$
\operatorname{logit}(p)=\ln \frac{p}{1-p}=\ln (p)-\ln (1-p)
$$

gdzie: ln - logarytm naturalny.

D. Hosmer, S. Lemeshow, Applied Logistic..., s. 49-51; S. Menard, Applied Logistic..., s. 12-14.

41 Wzór na szansę:

$$
O=\frac{p}{q}=\frac{p}{1-p}
$$

gdzie: $p$ - prawdopodobieństwo zajścia zdarzenia $Y ; q$ - prawdopodobieństwo niezajścia zdarzenia $Y$. 
uzupełnia je o cztery predyktory kontrolne KI-K4. Należy jednak zauważyć, że dane zawarte w tych modelach mają układ hierarchiczny, ponieważ poprawki są zakorzenione w projektach legislacyjnych (1196 poprawek jest zagnieżdżonych w 599 projektach). W rezultacie nie mogą być one niezależnymi obserwacjami, ponieważ prawdopodobieństwo ich sukcesu może mocno zależeć od materii, formy czy ważności projektu, w którym są zawarte, i w konsekwencji zaburzać wyniki. Obecność tego efektu potwierdza zresztą jednoczynnikowa analiza wariancji $(A N O V A)$, w której wartość statystyki $F$ uzyskała istotność statystyczną na najwyższym poziomie ${ }^{42}$. Oznacza to, że różnice między projektami mają widoczny wpływ na prawdopodobieństwo sukcesu poprawek Parlamentu w konsultacji. Aby zatem uwzględnić hierarchiczny układ poprawek i projektów oraz uniknąć zniekształceń wyników, oba powyższe modele oszacowano za pomocą odpornej regresji logistycznej (robust logistic regression), w której błędy standardowe zostały sklastrowane (pogrupowane hierarchicznie, ang. cluster).

\section{WYNIKI EMPIRYCZNEGO TESTU HIPOTEZ}

Wykres nr 2 przedstawia liczbę i udział poprawek Parlamentu, które zakończyły się sukcesem. Ogółem w latach 1999-2009 posłowie zgłosili w konsultacji 1196 modyfikacji legislacyjnych, z których 385 zostało inkorporowanych do finalnego aktu prawnego. Oznacza to, że tylko 32,2\% poprawek zakończyło się sukcesem. W liczbach bezwzględnych najwięcej żądań Parlamentu zostało zaakceptowanych w obszarze wolności, bezpieczeństwa i sprawiedliwości (110 poprawek), rolnictwa i rozwoju obszarów wiejskich (59) oraz budżetu (32), natomiast w wartościach względnych w zakresie spraw statystycznych (100\%), znów budżetowych (80\%) oraz prawnych $(69,2 \%)$. Powyższe wyniki potwierdzają zatem dominujący w literaturze pogląd, że z racji poważnie ograniczonej pozycji formalnoprawnej Parlament posiada niewielki wpływ na kształtowanie legislacji uchwalanej w konsultacji.

Tabela nr 2 przedstawia z kolei wyniki regresji logistycznej. Pierwszym krokiem jest ocena dopasowania modeli do danych (zob. dolna część tabeli nr 2). Sprowadza się ona do przeprowadzenia pięciu testów: współliniowości ${ }^{43}$, ilorazu wiarygodności ${ }^{44}$, Hosmera-Lemeshowa ${ }^{45}$, determinacji (pseudo- $R$-kwadrat McFaddena) ${ }^{46}$ i zdolności klasyfikacyjnych ${ }^{47}$. Można uznać, że oba modele zdały je z wynikiem satysfakcjonującym, o czym informują następujące obserwacje. Po pierwsze współczynniki $R$ i $V I F$

42 Wyniki testu: $F=1,546$ (p<0,01); suma kwadratów pomiędzy grupami - 370,276; suma kwadratów wewnątrz grup - 442,431.

43 S. Menard, Applied Logistic..., s. 75-78.

44 D. Hosmer, S. Lemeshow, Applied Logistic..., s. 13-16, 145-147.

45 Ciż, Goodness-of-Fit Tests for the Multiple Logistic Regression Model, „Communications in Statistics. Theory and Methods" 1980, Vol. 9, nr 10, s. 1043-1069, [online] http://dx.doi.org/10.1080/ 03610928008827941.

46 Ciż, Applied Logistic..., s. 164-167.

47 Tamże, s. 160-164. 
(variance inflation factor) zmiennych nie przekraczają wartości krytycznych $(R<0,8$, $V I F<5)$, co wyklucza obecność zjawiska współliniowości ${ }^{48}$. Po drugie w obu modelach wartości statystyk $G$ o rozkładzie chi-kwadrat posiadają istotność statystyczną na najwyższym poziomie $(p<0,01)$. Można zatem przyjąć, że oba modele są zdecydowanie lepsze od losowego (modelu bez zmiennych), a więc zdają test ilorazu wiarygodności. Po trzecie wyniki testu Hosmera-Lemeshowa nie są istotne statystycznie, na poziomie $\alpha=0,05$. Nie ma zatem podstaw do odrzucenia $H 0$, że modele są dobrze dopasowane. Po czwarte według uzyskanego $R$-kwadratu McFaddena oba modele wyjaśniają ok. 37\% wariancji zmiennej zależnej, co jest wynikiem satysfakcjonującym jak na regresję logistyczną. Po piąte oba modele posiadają przyzwoite zdolności klasyfikacyjne. Świadczy o tym fakt, że prawidłowo (zgodnie z rzeczywistością) przewidziały one sukces lub porażkę ok. 82\% wszystkich poprawek zgłoszonych przez Parlament w latach 1999-2009 w konsultacji. Ponadto interpretacja współczynników BIC (Bayesian Information Criterion $)^{49}$ prowadzi do wniosku, że model nr 1 jest znacznie lepiej dopasowany do danych niż model nr 2 i tym samym dogłębniej wyjaśnia sukces poprawek PE. Informuje o tym wartość jego BIC, która jest widocznie niższa niż w modelu nr $2^{50}$.

Po teście jakości dopasowania modeli można przejść do weryfikacji poszczególnych hipotez poprzez interpretację współczynników regresji $(\beta)$, błędów standardowych (S.E. - standard errors), ilorazów szans $(O R)$ oraz istotności statystycznej. Rozpoczynając od $H 1$, analiza wykazała, że pakietowanie pozytywnie wpływa na sukces poprawek Parlamentu w konsultacji. Rzeczona zmienna posiada bowiem dodatni współczynnik regresji oraz jest istotna statystycznie na najwyższym poziomie w obu modelach. $O R$ informuje, że, ceteris paribus, gdy Parlament łączy projekt konsultacyjny z wnioskiem legislacyjnym rozpatrywanym w tym samym czasie w ZPU lub w procedurze budżetowej albo gdy Komisja proponuje pakiet składający się z kilku projektów uchwalanych jednocześnie w różnych procedurach, to szansa na sukces poprawek Parlamentu wzrasta o ok. $125 \%$ w porównaniu do braku stosowania techniki pakietowej. Zgodnie zatem z przewidywaniami blokada kilku postępowań prawodawczych znacznie wzmacnia pozycję negocjacyjną Parlamentu, gdyż zmusza Radę do udzielania koncesji na rzecz posłów ${ }^{51}$. Brak ustępstw z jej strony jest bowiem równoznaczny z nieuchwaleniem kilku powiązanych ze sobą regulacji, co może opóźnić wprowadzenie reform w określonych sektorach czy skutkować poważnymi kosztami społeczno-ekonomicznymi dla państw członkowskich.

48 Najwyższy współczynnik $R$ wyniósł 0,680 (korelacja „EPP-ED” - „PES” w modelu nr 2), natomiast $V I F-2,091$ („EPP-ED”).

49 Zob.: A. Raftery, Bayesian Model Selection in Social Research, „Sociological Methodology” 1995, Vol. 25, s. 111-163, [online] http://dx.doi.org/10.2307/271063.

50 Różnica BIC obu modeli jest wyższa niż 10, co oznacza, że dopasowanie do danych modelu nr 1 jest zdecydowanie lepsze niż modelu nr 2. Zob.: tamże, s. 139.

51 Zob. też: R. Kardasheva, Package Deals in EU Legislative Politics, „American Journal of Political Science" 2013, Vol. 57, nr 4, s. 858-874, [online] http://dx.doi.org/10.1111/ajps.12035; taż, The Power to Delay..., s. 403; R. Trzaskowski, J. Popielawska, Rola Parlamentu Europejskiego we Wspólnej Polityce Zagranicznej i Bezpieczeństwa, [w:] Parlament Europejski po Traktacie z Lizbony. Doświadczenia i nowe wyzwania, red. J.M. Fiszer, Warszawa 2011, s. 37-38. 
Tabela 2. Wyniki regresji logistycznej - procedura konsultacji

\begin{tabular}{|c|c|c|c|c|c|}
\hline \multirow{3}{*}{$\begin{array}{l}\mathrm{Nr} \\
\text { hipotezy }\end{array}$} & \multirow{3}{*}{$\begin{array}{l}\text { Zmienna } \\
\text { niezależna }\end{array}$} & \multicolumn{4}{|c|}{ Zmienna zależna: sukces poprawek PE w konsultacji } \\
\hline & & \multicolumn{2}{|c|}{ Model nr 1} & \multicolumn{2}{|c|}{ Model nr 2} \\
\hline & & $\beta$ (S.E.) & $O R$ & $\beta$ (S.E.) & $O R$ \\
\hline \multicolumn{6}{|c|}{ Zmienne teoretyczne } \\
\hline $\mathrm{H} 1$ & Pakietowanie & $0,923(0,287)^{* * *}$ & $2,251^{* * *}$ & $0,953(0,296)^{* * *}$ & $2,596^{* * *}$ \\
\hline $\mathrm{H} 2$ & Opóźnienie & $1,516(0,428)^{* * *}$ & $4,556^{* * *}$ & $1,524(0,447)^{* * *}$ & $4,591^{* * *}$ \\
\hline $\mathrm{H} 3$ & Poparcie Komisji & $3,088(0,193)^{* * *}$ & $21,941^{* * *}$ & $3,187(0,193)^{* * *}$ & $24,220^{* * *}$ \\
\hline $\mathrm{H} 4$ & $\begin{array}{l}\text { Koniec kaden- } \\
\text { cji PE }\end{array}$ & $0,710(0,242)^{* * *}$ & $2,034^{* * *}$ & $0,650(0,243)^{* * *}$ & $1,916^{* * *}$ \\
\hline $\mathrm{H} 5$ & Ważność & $0,010(0,006)^{*}$ & $1,011^{*}$ & $0,010(0,006)^{*}$ & $1,010^{*}$ \\
\hline \multirow{3}{*}{ H6 i H7 } & $\begin{array}{l}\text { Poprawka } \\
\text { finansowa }\end{array}$ & $0,679(0,225)^{* * *}$ & $1,973^{* * *}$ & $0,708(0,226)^{* * *}$ & $2,030^{* * *}$ \\
\hline & $\begin{array}{l}\text { Poprawka } \\
\text { demokratyczna }\end{array}$ & $1,362(0,264)^{* * *}$ & $3,905^{* * *}$ & $1,476(0,279)^{* * *}$ & $4,378^{* * *}$ \\
\hline & $\begin{array}{l}\text { Poprawka } \\
\text { instytucjonalna }\end{array}$ & $\begin{array}{l}-0,389 \\
(0,212)^{*}\end{array}$ & $0,677^{*}$ & $-0,319(0,219)$ & 0,726 \\
\hline \multicolumn{6}{|c|}{ Zmienne kontrolne } \\
\hline $\mathrm{K} 1$ & $\begin{array}{l}\text { Zasada głosowania } \\
\text { w Radzie }\end{array}$ & - & - & $0,185(0,185)$ & 1,203 \\
\hline $\mathrm{K} 2$ & Dyrektywa & - & - & $0,778(0,293)^{* * *}$ & $2,178^{* * *}$ \\
\hline K3 & $\begin{array}{l}\text { Doświadczenie } \\
\text { sprawozdawcy }\end{array}$ & - & - & $0,012(0,019)$ & 1,012 \\
\hline \multirow{4}{*}{ K4 } & EPP-ED & - & - & $-0,303(0,252)$ & 0,738 \\
\hline & PES & - & - & $0,025(0,253)$ & 1,026 \\
\hline & ELDR/ALDE & - & - & $-0,151(0,312)$ & 0,859 \\
\hline & Stała & \multicolumn{2}{|c|}{$-3,026(0,199)^{* * *}$} & \multicolumn{2}{|c|}{$-3,213(0,302)^{* * *}$} \\
\hline \multicolumn{6}{|c|}{$\begin{array}{c}\text { Testy dobroci } \\
\text { dopasowania modeli }\end{array}$} \\
\hline & Test chi-kwadrat & \multicolumn{2}{|c|}{$309,14(8)^{* * *}$} & \multicolumn{2}{|c|}{$325,35(14)^{* * *}$} \\
\hline & $\begin{array}{l}\text { Test Hosmera- } \\
\text {-Lemeshowa }\end{array}$ & \multicolumn{2}{|c|}{$14,49(8)$} & \multicolumn{2}{|c|}{$14,52(8)$} \\
\hline & $\begin{array}{l}\text { Pseudo-R-kwadrat } \\
\text { (McFadden) }\end{array}$ & \multicolumn{2}{|c|}{0,366} & \multicolumn{2}{|c|}{0,373} \\
\hline & $\begin{array}{l}\text { Celność } \\
\text { klasyfikacji }\end{array}$ & \multicolumn{2}{|c|}{$82,27 \%$} & \multicolumn{2}{|c|}{$81,46 \%$} \\
\hline & $\mathrm{BIC}$ & \multicolumn{2}{|c|}{1015,624} & \multicolumn{2}{|c|}{1046,407} \\
\hline & $\mathrm{N}$ (postulaty) & \multicolumn{2}{|c|}{1196} & \multicolumn{2}{|c|}{1196} \\
\hline & $\mathrm{N}$ (projekty) & \multicolumn{2}{|c|}{599} & \multicolumn{2}{|c|}{599} \\
\hline
\end{tabular}

Objaśnienia: ${ }^{*}$ wyniki istotne w przedziale $p<0,1(10 \%) ;{ }^{* *} p<0,05(5 \%) ;{ }^{* * *} p<0,01$ (1\%). Wyniki istotne statystycznie zostały pogrubione. $N$ oznacza liczbę obserwacji. Liczby w nawiasach przy testach dobroci dopasowania modeli oznaczają stopnie swobody. 
Wykres 2. Sukces poprawek Parlamentu w procedurze konsultacji w latach 1999-2009 z perspektywy materii projektów

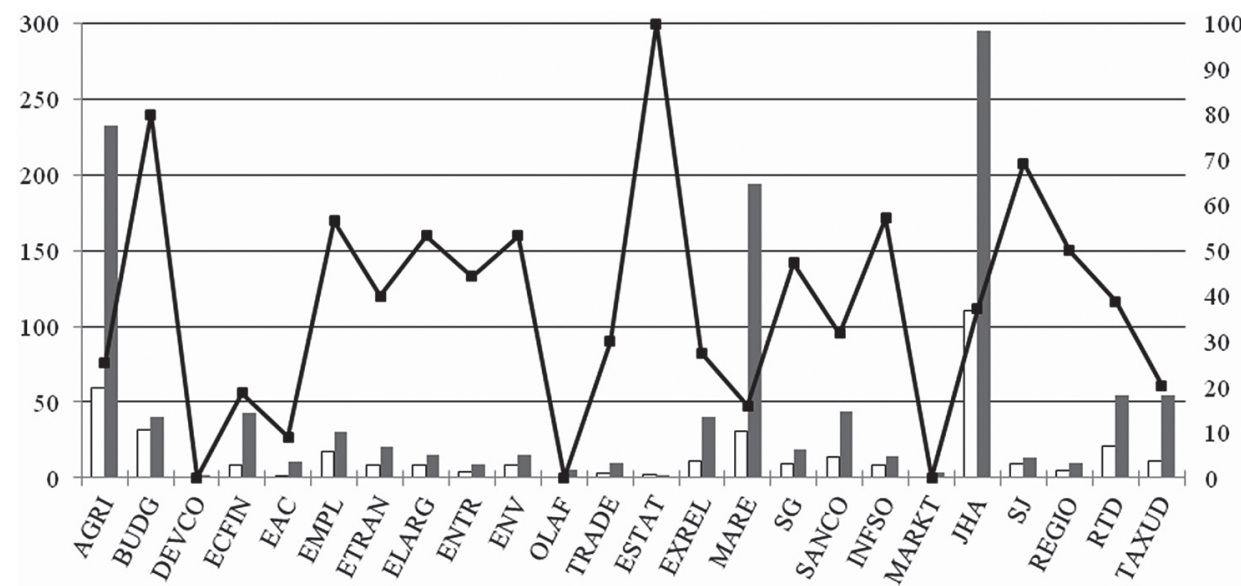

$\square$ Poprawki rozstrzygnięte na korzyść PE $\square$ Poprawki ogółem $\rightarrow$ Poziom sukcesu poprawek (\%)

Objaśnienia akronimów: AGRI - Dyrekcja Generalna (DG) Rolnictwo i Rozwój Obszarów Wiejskich; BUDG - DG Budżet; DEVCO - DG Rozwój i współpraca EuropeAid; ECFIN - DG Sprawy Gospodarcze i Finansowe; EAC - DG Edukacja i Kultura; EMPL - DG Zatrudnienie, Sprawy Społeczne i Włączenie Społeczne; ETRAN - DG Energia i Transport; ELARG - DG Rozszerzenie; ENTR - DG Przedsiębiorstwa i Przemysł; ENV - DG Środowisko; OLAF - Europejski Urząd ds. Zwalczania Nadużyć Finansowych; TRADE - DG Handel; ESTAT - DG Eurostat; EXREL - DG Stosunki Zewnętrzne; MARE - DG Gospodarka Morska i Rybołówstwo; SG - Sekretariat Generalny; SANCO - DG Zdrowie i Konsumenci; INFSO - DG Społeczeństwo Informacyjne i Media; MARKT - DG Rynek Wewnętrzny i Usługi; JHA - DG Sprawiedliwość, Sprawy Wewnętrzne i Bezpieczeństwo; SJ - Służba Prawna; REGIO DG Polityka Regionalna; RTD - DG Badania i Innowacje; TAXUD - DG Podatki i Unia Celna.

Lewa oś $Y$ - liczba poprawek, prawa oś $Y$ - procentowy udział poprawek rozstrzygniętych na korzyść PE w ogólnej liczbie poprawek.

Źródło: Obserwatorium legislacyjne Parlamentu Europejskiego, [online] http://www.europarl.europa.eu/ oeil/home/home.do, 15 XI 2015; Rejestr publiczny dokumentów Rady, [online] http://register.consilium. europa.eu/content/int?lang=PL\&typ=ADV, 15 XI 2015.

Zgodnie z H2 sukces Parlamentu w konsultacji jest również bardziej prawdopodobny, gdy opóźnia on uchwalenie swojej opinii. Współczynnik kierunkowy zmiennej "Opóźnienie” posiada bowiem dodatnią i istotną statystycznie na najwyższym poziomie wartość w obu modelach. Iloraz szans informuje, że, ceteris paribus, gdy Parlament opóźnia przyjęcie opinii w tej procedurze, szansa na akceptację jego poprawek wzrasta czterokrotnie w porównaniu do przypadków, w których posłowie nie stosują tej strategii. Opóźnianie jest bardzo skuteczną techniką, ponieważ uniemożliwia Radzie uchwalenie regulacji. Jest to szczególnie istotne w przypadku projektów pilnych, których nieprzyjęcie na czas może generować poważne koszty społeczno-ekonomiczne dla państw członkowskich. Rada musi wówczas pójść na ustępstwa, aby przekonać Parlament do odmrożenia opinii, gdyż tylko w ten sposób może zapobiec negatywnym konsekwencjom braku uchwalenia regulacji w terminie. Warto jednak dodać, że w latach 
1999-2009 Parlament skorzystał z prawa do opóźniania tylko w przypadku 37 projektów (6,1\% wszystkich). Uzyskany wynik informuje, że jeśli posłowie chcą być skuteczni w konsultacji, powinni znacznie częściej korzystać z tego nieformalnego instrumentu.

$\mathrm{Z}$ tabeli nr 2 wynika, że czynnikiem, który najbardziej wpływa na sukces poprawek Parlamentu w konsultacji, jest poparcie Komisji ${ }^{52}$. Rzeczony predyktor posiada dodatnią $\mathrm{i}$ istotną statystycznie wartość $\mathrm{w}$ obu modelach, i to na najwyższym poziomie $(p<0,01)$. Ceteris paribus, $g$ dy Komisja popiera poprawkę posłów, to szansa na jej inkorporację do finalnego aktu prawnego wzrasta aż 22-krotnie. Rezultat ten jest zatem zgodny z twierdzeniem racjonalistów, że w świetle art. 293 ust. 1 TFUE poparte poprawki Parlamentu mogą być odrzucone przez Radę tylko jednomyślnie, co znacznie zwiększa pozycję unijnej legislatury w konsultacji. Ale uzyskany wynik potwierdza także konstruktywistyczne przypuszczenie o socjalizacyjnym i deliberacyjnym potencjale Komisji w relacjach z Radą. Ponieważ obie teorie odmiennie wyjaśniają zaobserwowany efekt, pojawia się pytanie, która z nich jest właściwa. Odpowiedzi udziela tabela nr 3. Otóż w latach 1999-2009 Komisja zaakceptowała w sposób formalny tylko 42 poprawki (9,1\% wszystkich popartych), natomiast nieformalnie - 419 modyfikacji. Oznacza to, że w przypadku aż 90,9\% popartych poprawek nie miał zastosowania art. 293 ust. 1 TFUE, przez co Rada mogła je odrzucić łatwiejszą do osiągnięcia kwalifikowaną większością głosów (KWG). Mimo to poziomy sukcesu modyfikacji zaakceptowanych przez Komisję w sposób formalny i nieformalny są podobne (różnica niecałych 10\%). Stanowi to mocny dowód na zasadność uzasadnienia konstruktywistycznego. Regularne, intensywne i zamknięte dla publiczności kontakty między decydentami Komisji i Rady w prawie wszystkich organach struktury organizacyjnej tej drugiej instytucji doprowadziły zgodnie z prawem socjalizacji do powstania kooperacyjnej kultury postępowania, w której stanowisko Komisji jest traktowane przez członków Rady za wiarygodne i zasługujące na uznanie. Dlatego mimo braku formalnej inkorporacji do wniosku poprawki Parlamentu poparte przez Komisję są często akceptowane przez ministrów, choć w takiej sytuacji mogą oni je odrzucać łatwiejszą do osiągnięcia KWG. Wydaje się, że Komisja korzysta z dobrodziejstwa art. 293 ust. 1 TFUE tylko wtedy, gdy deliberacja jest zaburzona jakimiś czynnikami (np. ważnością projektu, nieudolnością prezydencji czy konfliktem w Radzie) i przeforsowanie jej stanowiska jest możliwe tylko za pomocą bardziej konfrontacyjnych instrumentów. Jak jednak pokazuje tabela nr 3, takie przypadki są sporadyczne. Reasumując, $H 3$ została potwierdzona.

Parlament jest również bardziej skuteczny w konsultacji, jeśli przeciąga negocjacje nad projektem na okres przed końcem kadencji. Informuje o tym współczynnik $\beta$ zmiennej „Koniec kadencji PE”, który jest dodatni i istotny statystycznie na najwyższym poziomie w obu modelach. Interpretacja $O R$ prowadzi do wniosku, że gdy w latach 1999-2009 Parlament przedłużał negocjacje nad projektem na okres sześciu miesięcy przed wyborami do PE, to szansa na sukces jego poprawek wzrastała dwukrotnie

52 Zob. też opinie praktyków, że Komisja odgrywa kluczową rolę w konsultacji: R. Thomson, M. Hosli, Who has Power in the EU? The Commission, Council and Parliament in Legislative Decision-Making, „Journal of Common Market Studies" 2006, Vol. 44, nr 2, s. 399. 
w porównaniu do wniosków rozstrzyganych w innym okresie. Można zatem stwierdzić, że $H 4$ jest prawidłowa.

Tabela 3. Poprawki Parlamentu poparte formalnie i nieformalnie przez Komisję w procedurze konsultacji w latach 1999-2009

\begin{tabular}{|l|c|c|c|}
\hline & $\begin{array}{c}\text { Nieformalne } \\
\text { poparcie }\end{array}$ & $\begin{array}{c}\text { Formalne } \\
\text { poparcie }\end{array}$ & $\begin{array}{c}\text { Poparcie } \\
\text { ogółem }\end{array}$ \\
\hline Liczba poprawek popartych & 419 & 42 & 461 \\
\hline Udział poprawek popartych (\%) & $35 \%$ & $3,5 \%$ & $38,5 \%$ \\
\hline $\begin{array}{l}\text { Liczba poprawek popartych } \\
\text { zakończonych sukcesem }\end{array}$ & 279 & 32 & 311 \\
\hline $\begin{array}{l}\text { Udział poprawek popartych } \\
\text { zakończonych sukcesem (\%) }\end{array}$ & $66,5 \%$ & $76,1 \%$ & $67,4 \%$ \\
\hline
\end{tabular}

Źródło: PreLex.

Zgodnie z H5 ważność projektu ma również widoczny wpływ na sukces poprawek Parlamentu. Współczynnik kierunkowy opisującej ją zmiennej posiada dodatnią wartość oraz istotność statystyczną na niskim poziomie w obu modelach. Ceteris paribus, wzrost ważności aktu prawnego o jednostkę, a więc o jeden motyw, skutkuje zwiększeniem szansy akceptacji postulatów o zaledwie 1,1\%. Uzyskany rezultat oznacza, że ekonomiczne rozkładanie sił jest skuteczną techniką w konsultacji. Parlament powinien zatem kumulować wszystkie swoje zasoby na negocjowaniu projektów najważniejszych dla UE oraz unikać nadmiernej rywalizacji z Radą o kształt regulacji nieistotnych. W ten sposób nie rozprasza swoich zasobów, dzięki czemu jest w stanie przeforsować więcej kluczowych poprawek.

Analiza regresji wykazała również, że w latach 1999-2009 poprawki demokratyczne charakteryzowały się największym prawdopodobieństwem sukcesu. Wskazuje na to dodatnia i istotna statystycznie na najwyższym poziomie wartość współczynnika $\beta$ tej zmiennej obserwowana w obu modelach. Przy utrzymaniu innych predyktorów na stałym poziomie szansa sukcesu poprawki demokratycznej była w badanym okresie prawie czterokrotnie wyższa w porównaniu do poprawki materialnej (kategoria porównawcza). Można zatem uznać, że $H 7$ została potwierdzona. Jednocześnie wyniki nie udowodniły słuszności $H 6$. Co prawda współczynnik regresji zmiennej „Poprawka finansowa" jest istotny statystycznie, i to na najwyższym poziomie, we wszystkich modelach, ale ma dodatni znak. Oznacza to, że, wbrew przewidywaniom, sukces poprawek dotyczących spraw budżetowych był bardziej prawdopodobny niż modyfikacji materialnych. Obserwacja ta stoi zatem w sprzeczności z podnoszonym w literaturze twierdzeniem, że unijna legislatura powinna być bardziej wpływowa w przypadku spraw regulacyjnych niż redystrybucyjnych. Uzyskany efekt można wyjaśnić kumulacją kilku czynników: szczególną ważnością projektów budżetowych uchwalanych w konsultacji w latach 1999-200953, konfliktowym i skutecznym postępowaniem Komisji PE

53 W badanym okresie w konsultacji uchwalono wiele projektów określających kwoty budżetowe programów unijnych, np. GALILEO, CARDS, TEMPUS, MEDIA PLUS, MEDA, 6 i 7 Program Ramowy 
ds. Budżetu (BUDG), która odpowiadała za największą liczbę opóźnień i pakietów, czy widoczną koncentracją uwagi Parlamentu na tych propozycjach legislacyjnych (ogółem najwięcej opóźnień i pakietów). Poza tym z tabeli nr 2 wynika, że w badanym okresie Parlament miał niewielkie szanse na przekonanie Rady do akceptacji poprawek instytucjonalnych, co jest zgodne $\mathrm{z}$ dominującym w literaturze poglądem ${ }^{54}$. Jakościowa analiza projektów uchwalonych w konsultacji w latach 1999-2009 pokazuje, że posłowie proponowali modyfikacje zwiększające uprawnienia legislacyjne Parlamentu, które można sprowadzić do trzech grup: częste i bardziej szczegółowe informowanie Parlamentu o podjętych decyzjach lub wydatkowaniu budżetowym (raporty Komisji, sprawozdania z posiedzeń komitetów komitologicznych), zmiana procedury komitologicznej na korzystniejszą dla Parlamentu (np. doradczą na regulacyjną połączoną z kontrolą) czy wprowadzanie tylnymi drzwiami procedur prawodawczych przy rozstrzyganiu materii leżących w gestii innych instytucji (zastępowanie komitologii współdecydowaniem, wybór kierownictwa agencji za zgodą Parlamentu). Większość tych poprawek wykraczała poza ramy Traktatów i nie uzyskiwała nawet poparcia Komisji. Dlatego negatywny i istotny statystycznie na średnim poziomie współczynnik $\beta$ zmiennej „Poprawka instytucjonalna” w modelu nr 1 nie powinien dziwić.

Przechodząc do zmiennych kontrolnych, uzyskano następujące rezultaty. Po pierwsze analiza regresji ujawniła tylko jeden widoczny efekt - wpływ formy aktu prawnego. Dowodzi tego współczynnik $\beta$ predyktora „Dyrektywa”, który jest istotny statystycznie na najwyższym poziomie w modelu $\mathrm{nr} 2$. Gdy zatem w latach 1999-2009 przedmiotem negocjacji w konsultacji była dyrektywa, to szansa sukcesu poprawek Parlamentu wzrastała dwukrotnie, przy utrzymaniu pozostałych czynników na stałym poziomie. Po drugie zasada głosowania w Radzie nie wpływa na sukces poprawek Parlamentu. Predyktor ten nie wykazuje bowiem istotności statystycznej w żadnym modelu. Otrzymany wynik stoi zatem $\mathrm{w}$ sprzeczności z przewidywaniami teorii racjonalistycznych, w szczególności proceduralnych modeli przestrzennych, które dowodzą, że podejmowanie decyzji KWG powinno zwiększać szanse posłów na przeforsowanie własnych poprawek w konsultacji. Wzmacnia natomiast przypuszczenie konstruktywistów, że w aspekcie międzyinstytucjonalnym funkcjonująca w Radzie kultura konsensu niweluje znaczenie formalnych reguł głosowania, umożliwiając nawet w szczególnie konfliktowych sytuacjach cechujących się skrajną różnorodnością preferencji osiągnięcie jednomyślności i odpieranie roszczeń posłów ${ }^{55}$. Po trzecie zmienna „Doświadczenie sprawozdawcy” nie

Wspólnoty Europejskiej i Euratomu w zakresie badań, ustanawiających budżety agencji czy modyfikujących linie w budżecie UE.

54 R. Kardasheva, The Power to Delay..., s. 391.

55 Zob. np.: D. Heisenberg, The Institution of 'Consensus' in the European Union. Formal versus Informal Decision-Making in the Council, „European Journal of Political Research” 2005, Vol. 44, nr 1, s. 65-90; D. Naurin, Most Common When Least Important. Deliberation in the European Council of Ministers, „British Journal of Political Science” 2010, Vol. 40, nr 1, s. 31-50, [online] http://dx.doi.org/10.1017/ S0007123409990251; J. Lewis, The Janus Face of Brussels..., s. 943, 949; tenże, Is the 'Hard Bargaining' Image of the Council Misleading? The Committee of Permanent Representatives and the Local Elections Directive, „Journal of Common Market Studies” 1998, Vol. 36, nr 4, s. 479-504. 
wykazała istotności statystycznej w obu modelach. Staż parlamentarzysty pełniącego tę funkcję nie zwiększa zatem prawdopodobieństwa sukcesu poprawek Parlamentu. Po czwarte nie znaleziono dowodów na twierdzenie, że sukces Parlamentu jest bardziej prawdopodobny, gdy sprawozdawca należy do jednej z największych frakcji: EPP-ED, PES lub ELDR/ALDE.

\section{KONKLUZJE}

Konsultacja jest jedną ze specjalnych procedur ustawodawczych, w której uchwala się obecnie ok. 8-10\% wszystkich aktów ustawodawczych. Choć jej zakres zastosowania jest wąski, to są w niej przyjmowane kluczowe regulacje unijne dotyczące m.in. zabezpieczenia społecznego i ochrony socjalnej (art. 21 ust. 3 TFUE), paszportów, dowodów tożsamości i dokumentów pobytowych (art. 77 ust. 3 TFUE), transgranicznej współpracy organów sądowych i policyjnych (art. 89 TFUE), harmonizacji podatków pośrednich (art. 113 TFUE), zbliżania ustawodawstw w sprawie rynku wewnętrznego (art. 115 TFUE), nadzoru nad instytucjami finansowymi (art. 127 ust. 6 TFUE), polityki zatrudnienia (art. 148 ust. 2 TFUE), badań i rozwoju technologicznego (art. 182 ust. 4 TFUE) czy źródeł energii (art. 192 ust. 2(c) TFUE). Specyfiką konsultacji jest bardzo słaba pozycja formalnoprawna Parlamentu Europejskiego, która sprowadza się jedynie do konsultowania projektów. Rada nie jest związana opinią posłów i de facto samodzielnie przyjmuje akty prawne w tej procedurze. Mimo to w artykule postawiono pytanie: czy są jakieś czynniki lub techniki negocjacyjne, które zapewniają większy sukces poprawek Parlamentu zgłoszonych w konsultacji.

W celu odpowiedzi na to pytanie zaproponowano kilka hipotez badawczych, które następnie zweryfikowano empirycznie za pomocą regresji logistycznej, wykorzystując do tego unikatową bazę danych składającą się z 599 aktów prawnych uchwalonych w latach 1999-2009 w konsultacji. Rezultaty tego testu dostarczyły pięciu rekomendacji informujących, w jaki sposób Parlament ma negocjować, aby przeforsować swoje poprawki w tej procedurze. Po pierwsze powinien pakietować, czyli blokować przebieg zwykłej procedury ustawodawczej, budżetowej lub zgody, w których posiada istotne kompetencje legislacyjne, uzależniając ich odblokowanie od zaakceptowania przez Radę poprawek zgłoszonych przez Parlament w konsultacji. Po drugie powinien opóźniać przyjęcie swojej opinii w sprawie projektu. Po trzecie powinien formułować swoje poprawki w taki sposób, aby uzyskać dla nich formalne lub nieformalne poparcie ze strony Komisji Europejskiej. Po czwarte powinien przeciągać negocjacje legislacyjne na okres sześciu miesięcy przed końcem kadencji. Po piąte powinien kierować się zasadą ekonomii sił, to znaczy kumulować wszystkie swoje zasoby na rozstrzyganiu projektów najważniejszych dla UE i odpuszczać walkę o kształt wniosków mało istotnych.

Badanie empiryczne wykazało również, że w latach 1999-2009 Parlament był najbardziej skuteczny w negocjowaniu poprawek dotyczących demokracji i praw człowieka oraz, co jest pewnym zaskoczeniem, finansów UE. Miał natomiast widoczne 
problemy z forsowaniem postulatów zwiększających jego uprawnienia instytucjonalno-legislacyjne. Ponadto w badanym okresie prawdopodobieństwo sukcesu wszystkich poprawek PE było istotnie większe w przypadku dyrektyw niż rozporządzeń czy decyzji. Jednocześnie analiza nie potwierdziła, aby zasada głosowania w Radzie, doświadczenie sprawozdawcy i jego przynależność do największych grup politycznych (EPP-ED, PES lub ELDR/ALDE) widocznie zwiększały lub zmniejszały szansę akceptacji poprawek Parlamentu.

\section{BIBLIOGRAFIA}

\section{Źródła}

Judgment of the Court of 29 October 1980 - SA Roquette Freires $v$ Council of the European Communities, Case C-138/79, „European Court Reports” 1980.

Judgment of the Court of 29 October 1980 - Maizena GmbH v Council of the European Communities, Case C-139/79, „European Court Reports” 1980.

Obserwatorium legislacyjne Parlamentu Europejskiego, [online] http://www.europarl.europa.eu/ oeil/home/home.do.

Rejestr publizny dokumentów Rady, [online] http://register.consilium.europa.eu/content/int? lang $=\mathrm{PL} \& \mathrm{typ}=\mathrm{ADV}$.

Traktaty Rzymskie (Traktat ustanawiajacy Europejska Wspólnotę Gospodarcza, Traktat ustanawiający Europejską Wspólnotę Energii Atomowej), Rzym, 25 III 1957, [online] http://eur-lex.europa.eu/legal-content/PL/TXT/?uri=CELEX:11957E/TXT.

Wersja skonsolidowana Traktatu ofunkcjonowaniu Unii Europejskiej, Dz. U. UE 2012, C 326, s. 172 , art. 289 ust. 1.

\section{Monografie i opracowania zbiorowe}

Cooper C., Theories of Organizational Stress, Oxford-New York 1998.

Hosmer D., Lemeshow S., Applied Logistic Regression, New York 2000.

Kapteyn P., Verloren van Themaat P., Introduction to the Law of the European Communities. After the Coming into Force of the Single European Act, Deventer 1990.

Menard S., Applied Logistic Regression, Thousand Oaks 2002.

Perrow C., Organizational Analysis. A Sociological Views, Belmont, Calif. 1970, Behavioral Science in Industry Series.

Raiffa H., The Art and Science of Negotiation, Cambridge, Mass. 1982.

The New Institutionalism in Organizational Analysis, red. W. Powell, P. DiMaggio, Chicago 1991.

Westlake M., A Modern Guide to the European Parliament, London 1994.

Węc J.J., Spór o ksztalt instytucjonalny Wspólnot Europejskich i Unii Europejskiej 1950-2005. Między idea ponadnarodowości a wspótpraca międzyrządowa. Analiza politologiczna, Kraków 2006, Societas - Księgarnia Akademicka, 8.

Węc J.J., Traktat Lizboński. Polityczne aspekty reformy ustrojowej Unii Europejskiej w latach 2007-2009, Kraków 2011, Societas - Księgarnia Akademicka, 36. 


\section{Artykuły}

Bailer S., What Factors Determine Bargaining Power and Success in EU Negotiations?, „Journal of European Public Policy" 2010, Vol. 17, nr 5, [online] http://dx.doi.org/10.1080/ 13501761003748765.

Bailer S., Schneider G., Nash versus Schelling? The Importance of Constraints in Legislative Bargaining, [w:] The European Union Decides, red. R. Thomson i in., Cambridge 2006, Political Economy of Institutions and Decisions.

Boyron S., The Consultation Procedure. Has the Court of Justice Turned against the European Parliament?, „European Law Review” 1996, Vol. 21.

Burns C., Who Pays? Who gains? How do Costs and Benefits Shape the Policy Influence of the European Parliament, „Journal of Common Market Studies” 2005, Vol. 43, nr 3.

Checkel J., International Institutions and Socialization in Europe. Introduction and Framework, „International Organization” 2005, Vol. 59, nr 4.

Costello R., Thomson R., The Distribution of Power Among EU Institutions. Who Wins Under Codecision and Why?, „Journal of European Public Policy” 2013, Vol. $20, \mathrm{nr} 7$.

Crombez C., Legislative Procedures in the European Community, „British Journal of Political Science” 1996, Vol. 26, nr 2, [online] http://dx.doi.org/10.1017/S0007123400000429.

Dür A., Mateo G., Bargaining Power and Negotiation Tactics. The Negotiations on the EU's Financial Perspective, 2007-2013, „Journal of Common Market Studies” 2010, Vol. 48, nr 3.

Egeberg M., Transcending Intergovernmentalism? Identity and Role Perceptions of National Officials in EU Decision-Making, „Journal of European Public Policy” 1999, Vol. 6, nr 3.

Elgström O., Jönsson C., Negotiation in the European Union. Bargaining or Problem-Solving?, „Journal of European Public Policy” 2000, Vol. 7, nr 5.

Farrell H., Héritier A., Interorganizational Negotiation and Intraorganizational Power in Shared Decision Making. Early Agreements Under Codecision and Their Impact on the European Parliament and Council, „Comparative Political Studies” 2004, Vol. 37, nr 10.

Häge F., Committee Decision-Making in the Council of the European Union, „European Union Politics” 2007, Vol. 8, nr 3, [online] http://dx.doi.org/10.1177/1465116507079539.

Häge F., The European Union Policy-Making Dataset, „European Union Politics” 2011, Vol. 12, nr 3, [online] http://dx.doi.org/10.1177/1465116511398739.

Hartley T., Consulting the European Parliament, „European Law Review” 1981, Vol. 6.

Heisenberg D., The Institution of 'Consensus' in the European Union. Formal versus Informal Decision-Making in the Council, „European Journal of Political Research” 2005, Vol. 44, nr 1.

Hertz R., Leuffen D., Gridlock after Enlargement? An Analysis of Legislative Output in the European Union, paper presented at EUSA conference, Los Angeles, CA, 23-25 IV 2009.

Hosmer D., Lemeshow S., Goodness-of-Fit Tests for the Multiple Logistic Regression Model, „Communications in Statistics. Theory and Methods" 1980, Vol. 9, nr 10, [online] http://dx.doi. org/10.1080/03610928008827941.

Jacobs F., Isoglucose Resurgent. Two Powers of the European Parliament Upheld by the Court, „Common Market Law Review” 1981, Vol. 18.

Judge D., Earnshaw D., Ngaire C., Ripples or Waves. The European Parliament in the European Community Policy Process, „Journal of European Public Policy” 1994, Vol. 1, nr 1. 
Kardasheva R., The Power to Delay. The European Parliament's Influence in the Consultation Procedure, „Journal of Common Market Studies” 2009, Vol. 47, nr 2.

Kardasheva R., Package Deals in EU Legislative Politics, „American Journal of Political Science” 2013, Vol. 57, nr 4, [online] http://dx.doi.org/10.1111/ajps.12035.

Kirchner E., Williams K., The Legal, Political and Institutional Implications of the Isoglucose Judgments 1980, „Journal of Common Market Studies” 1983, Vol. 22, nr 2.

Kirpsza A., Charakterystyka konsultacji jako specjalnej procedury ustawodawczej Unii Europejskiej, „Stosunki Międzynarodowe - International Relations” 2012, Vol. 46, nr 2.

Kirpsza A., Zastosowanie regresji logistycznej w studiach nad Uniq Europejska, [w:] Metody jakościowe i ilościowe w badaniu organizacji i dziatania Unii Europejskiej, red. K. Eawniczak, Warszawa 2013.

Kirpsza A., Analiza zjawiska wczesnych nieformalnych porozumień legislacyjnych w zwyktej procedurze ustawodawczej, „Studia Europejskie” 2013, nr 4.

Laruelle A., The EU Decision-Making Procedures. Some Insight from Non Co-Operative Game Theory, [w:] Institutional Challenges in the European Union, red. A. van Deemen, M. Widgrén, M. Hösli, London 2002, Routledge Advances in European Politics, 6.

Leuffen D., Hertz R., If Things Can Only Get Worse. Anticipation of Enlargement in the European Union, „European Journal of Political Research” 2010, Vol. 49, nr 1.

Lewis J., Is the 'Hard Bargaining' Image of the Council Misleading? The Committee of Permanent Representatives and the Local Elections Directive, "Journal of Common Market Studies” 1998, Vol. 36, nr 4.

Lewis J., The Janus Face of Brussels. Socialization and Everyday Decision Making in the European Union, „International Organization” 2005, Vol. 59, nr 4.

Lewis J., How Institutional Environments Facilitate Co-Operative Negotiation Styles in EU Decision-Making, ,Journal of European Public Policy” 2010, Vol. 17, nr 5, [online] http:// dx.doi.org/10.1080/13501761003748591.

Lowi T., Four Systems of Policy, Politics and Choice, "Public Administration Review” 1972, Vol. 32, nr 4, [online] http://dx.doi.org/10.2307/974990.

McKibben H.E., Issue Characteristics, Issue Linkage, and States' Choice of Bargaining Strategies in the European Union, „Journal of European Public Policy” 2010, Vol. 17, nr 5.

Napel S., Widgrén M., Strategic versus Non-strategic Voting Power in the EU Council of Ministers. The Consultation Procedure, „Social Choice and Welfare” 2011, Vol. 37, nr 3, [online] http://dx.doi.org/10.1007/s00355-010-0502-5.

Naurin D., Most Common When Least Important. Deliberation in the European Council of Ministers, „British Journal of Political Science” 2010, Vol. 40, nr 1, [online] http://dx.doi. org/10.1017/S0007123409990251.

O'Neill M., European Law - Case C-65/93 and the European Parliament's Right of Consultation: Community Institutional Balance in Action, „Dublin University Law Journal” 1996, Vol. 3, nr 1.

Raftery A., Bayesian Model Selection in Social Research, "Sociological Methodology” 1995, Vol. 25, [online] http://dx.doi.org/10.2307/271063.

Rasmussen A., The Role of the European Commission in Co-Decision. A Strategic Facilitator Operating in a Situation of Structural Disadvantage, „European Integration online Papers” 2003, Vol. 7 , nr 10. 
Rasmussen A., Reh C., The Consequences of Concluding Codecision Early. Trilogues and Intra-Institutional Bargaining Success, „Journal of European Public Policy” 2013, Vol. 20, nr 7.

Reh C., Is Informal Politics Undemocratic? Trilogues, Early Agreements and the Selection Model of Representation, „Journal of European Public Policy” 2014, Vol. 21, nr 6, [online] http:// dx.doi.org/10.1080/13501763.2014.910247.

Reh C. i in., The Informal Politics of Legislation. Explaining Secluded Decision Making in the European Union, „Comparative Political Studies” 2011, Vol. 46, nr 9.

Ripoll Servent A., Playing the Co-Decision Game? Rules' Changes and Institutional Adaptation at the LIBE Committee, „Journal of European Integration” 2012, Vol. 34, nr 1.

Scully R., Policy Influence and Participation in the European Parliament, „Legislative Studies Quarterly” 1997, Vol. 22, nr 2, [online] http://dx.doi.org/10.2307/440384.

Scully R., The European Parliament and the Co-decision Procedure. A Reassessment, „Journal of Legislative Studies" 1997, Vol. 3, nr 3, [online] http://dx.doi.org/10.1080/13572339708420518.

Shackleton M., The Politics of Codecision, „Journal Common Market Studies” 2000, Vol. 38, nr 2.

Shackleton M., Raunio T., Codecision since Amsterdam. A Laboratory for Institutional Innovation and Change, "Journal of European Public Policy” 2003, Vol. 10, nr 2.

Thomson R., Boerefijn J., Stokman F., Actor Alignments in European Union Decision Making, „European Journal of Political Research” 2004, Vol. 43, nr 2, [online] http://dx.doi. org/10.1111/j.1475-6765.2004.00153.x.

Thomson R., Hosli M., Who has Power in the EU? The Commission, Council and Parliament in Legislative Decision-Making, ,Journal of Common Market Studies” 2006, Vol. 44, nr 2.

Trzaskowski R., Popielawska J., Rola Parlamentu Europejskiego we Wspólnej Polityce Zagranicznej i Bezpieczeństwa, [w:] Parlament Europejski po Traktacie z Lizbony. Doświadczenia i nowe wyzwania, red. J.M. Fiszer, Warszawa 2011.

Tsebelis G., Garrett G., Legislative Politics in the EU, „European Union Politics” 2000, Vol. 1, nr 1.

Tsebelis G., Garrett G., The Institutional Foundations of Intergovernmentalism and Supranationalism in the European Union, „International Organization” 2001, Vol. 55, nr 2.

Warntjen A., Between Bargaining and Deliberation. Decision-making in the Council of the European Union, „Journal of European Public Policy” 2010, Vol. 17, nr 5.

Varela D., Just a Lobbyist? The European Parliament and the Consultation Procedure, „European Union Politics" 2009, Vol. 10, nr 1.

Dr Adam Stanisław KIRPSZA - doktor nauk społecznych w zakresie nauk o polityce, asystent w Instytucie Nauk Politycznych i Stosunków Międzynarodowych Uniwersytetu Jagiellońskiego, absolwent prawa na Wydziale Prawa i Administracji UJ. Obszar jego zainteresowań koncentruje się wokół procesu podejmowania decyzji w Unii Europejskiej, prawa UE, prawa podatkowego, teorii stosunków międzynarodowych i integracji europejskiej, zastosowania mechaniki kwantowej w naukach społecznych oraz zjawiska biometryzacji przepływu osób. 